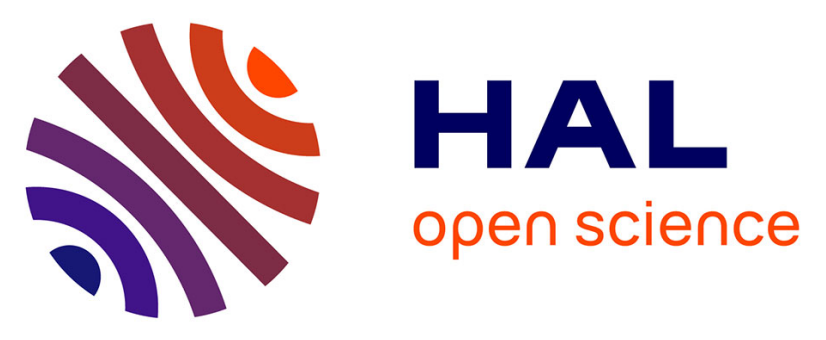

\title{
An integrated palaeoenvironmental investigation of a 6200 year old peat sequence from Ile de la Possession, Iles Crozet, sub-Antarctica
}

N. van Der Putten, J.P. Hébrard, C. Verbruggen, B. van de Vijver, Jean-Robert Disnar, S. Spassov, Jacques-Louis de Beaulieu, M. de Dapper, Didier Kéravis, Jozef Hus, et al.

\section{To cite this version:}

N. van Der Putten, J.P. Hébrard, C. Verbruggen, B. van de Vijver, Jean-Robert Disnar, et al.. An integrated palaeoenvironmental investigation of a 6200 year old peat sequence from Ile de la Possession, Iles Crozet, sub-Antarctica. Palaeogeography, Palaeoclimatology, Palaeoecology, 2008, 270 (1-2), pp.179-195. 10.1016/j.palaeo.2008.09.014 . insu-00342423

\section{HAL Id: insu-00342423 \\ https://hal-insu.archives-ouvertes.fr/insu-00342423}

Submitted on 27 Nov 2008

HAL is a multi-disciplinary open access archive for the deposit and dissemination of scientific research documents, whether they are published or not. The documents may come from teaching and research institutions in France or abroad, or from public or private research centers.
L'archive ouverte pluridisciplinaire HAL, est destinée au dépôt et à la diffusion de documents scientifiques de niveau recherche, publiés ou non, émanant des établissements d'enseignement et de recherche français ou étrangers, des laboratoires publics ou privés. 


\title{
An integrated palaeoenvironmental investigation of a 6200 year old peat sequence from Ile de la Possession, Iles Crozet, sub- Antarctica
}

\author{
N. Van der Putten ${ }^{\text {a, b, }}$, J.-P. Hébrard ${ }^{b}$, C. Verbruggen ${ }^{a}$, B. Van de Vijver ${ }^{c}$, J.-R. \\ Disnar $^{\mathrm{d}}$, S. Spassov ${ }^{\mathrm{e}}$, J.-L. de Beaulieu ${ }^{\mathrm{b}}$, M. De Dapper ${ }^{\mathrm{a}}$, D. Keravis ${ }^{\mathrm{d}}$, J. Hus ${ }^{\mathrm{e}}$, N. \\ Thouveny ${ }^{\mathrm{f}}$ and Y. Frenot ${ }^{\mathrm{g}}$
}

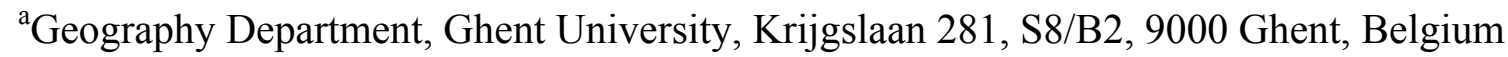

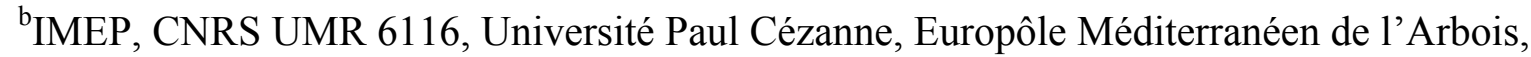
Bâtiment Villemin, Avenue Philibert BP 80, F-13545 Aix-en-Provence Cedex 04, France

${ }^{\mathrm{c}}$ National Botanic Garden of Belgium, Department of Cryptogamy (Bryophyta \& Thallophyta), Domein van Bouchout, 1860 Meise, Belgium

${ }^{\mathrm{d}}$ Institut des Sciences de la Terre d'Orléans (ISTO), UMR 6113 - CNRS/Université d'Orléans, 1A, rue de la Férollerie, 45071 Orléans, France

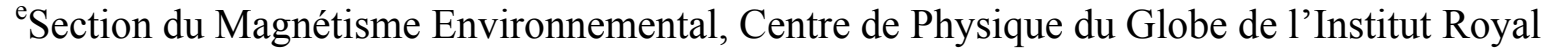
Météorologique de Belgique, B-5670, Dourbes (Viroinval), Belgium

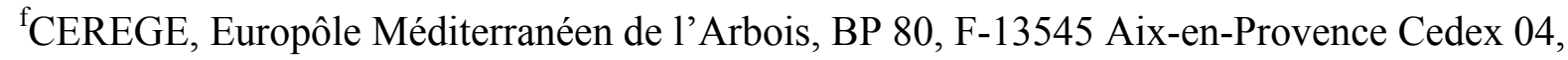
France

${ }^{g}$ UMR ECOBIO, CNRS, Université de Rennes I et Institut Polaire Français Paul Émile Victor (IPEV), Technopôle Brest Iroise, BP75, 29280 Plouzané, France 


\begin{abstract}
A 6200 year old peat sequence, cored in a volcanic crater on the sub-Antarctic Ile de la Possession (Iles Crozet), has been investigated, based on a multi-proxy approach. The methods applied are macrobotanical (mosses, seeds and fruits) and diatom analyses, complemented by geochemical (Rock-Eval6) and rock magnetic measurements. The chronology of the core is based on 5 radiocarbon dates.
\end{abstract}

When combining all the proxy data the following changes could be inferred. From the onset of the peat formation (6200 cal yr BP) until ca. $5550 \mathrm{cal} \mathrm{yr} \mathrm{BP,} \mathrm{biological} \mathrm{production} \mathrm{was}$ high and climatic conditions must have been relatively warm. At ca. $5550 \mathrm{cal}$ yr BP a shift to low biological production occurred, lasting until ca. $4600 \mathrm{cal}$ yr BP. During this period the organic matter is well preserved, pointing to a cold and/or wet environment. At ca. $4600 \mathrm{cal}$ yr BP, biological production increased again. From ca. 4600 cal yr BP until ca. 4100 cal yr BP a "hollow and hummock" micro topography developed at the peat surface, resulting in the presence of a mixture of wetter and drier species in the macrobotanical record. After ca. 4100 cal yr BP, the wet species disappear and a generally drier, acidic bog came into existence. A major shift in all the proxy data is observed at ca. $2800 \mathrm{cal} \mathrm{yr} \mathrm{BP,} \mathrm{pointing} \mathrm{to}$ wetter and especially windier climatic conditions on the island probably caused by an intensification and/or latitudinal shift of the southern westerly belt. Caused by a stronger wind regime, erosion of the peat surface occurred at that time and a lake was formed in the peat deposits of the crater, which is still present today.

Keywords: Palaeoecology; Palaeoclimate; Macrofossil record; Rock magnetism; Geochemical analysis; Diatoms; Iles Crozet; Sub-Antarctic; Holocene

\title{
1. Introduction
}

For the last decade, climatic connections between the northern and southern hemisphere and the driving mechanism behind were important issues in research on past climate and environmental change ([Bard et al., 1997], [Denton et al., 1999], [Blunier and Brook, 2001] and [Steig and Alley, 2002]). This research focused mainly on data from the Last Glacial Period and Glacial-Interglacial transition. Evidence from ice cores showed an asynchronous pattern of climate change in the Antarctic and the northern hemisphere (Blunier et al., 1998). The Antarctic Taylor Dome ice core (western Ross Sea sector), however, showed synchronous climatic changes between both hemispheres during the last deglaciation (Steig et al., 1998). Correlation of ice-core records from Greenland and marine records in the North Atlantic has revealed that thermohaline circulation, induced by the formation of North Atlantic Deep Water, plays an important role in the Earth's climate system (Bond et al., 1993). More recently, it became clear that the Southern Ocean plays a more prominent role in this context than was thought before (Knorr and Lohmann, 2003). The Southern Ocean forms the only connection between the Atlantic, Indian and Pacific Oceans and is characterized by several oceanic fronts of which the Polar Frontal Zone (also Antarctic Convergence), where cold northward-flowing Antarctic water masses confront and sink beneath warmer subAntarctic water masses, seems to be the most important. The Polar Frontal Zone (PFZ) has been proposed as the boundary between Antarctica's climate and that of the rest of the world ([Broecker, 1996], [Bard et al., 1997] and [Domack and Mayewski, 1999]). From an atmospheric point of view, sub-Antarctic islands are situated in these latitudes that are constantly influenced by the southern westerly belt. The modern location of the Southern 
Westerlies is strongly related to the steepest Sea Surface Temperatures (SST) within the Antarctic Circumpolar Current (ACC) (Lamy et al., 2002), and thus also with the PFZ.

Till today, palaeoclimatological records from the mid- and high-southern latitudes are scarce compared to the data available for the same latitudes in the northern hemisphere, especially for the Holocene. Terrestrial records on the Antarctic continent were reviewed by Ingolfsson et al. (1998) and Hodgson et al. (2004). Several papers on marine records have been published during the last decade. Most of these marine cores were taken in the Antarctic Peninsula region or near the coast of the Antarctic continent. Some of them, however, were cored in the area of the Polar Frontal Zone ([Hodell et al., 2001] and [Nielsen et al., 2004]). Sub-Antarctic islands are the only terrestrial archives present in the circum-Antarctic ocean which makes them an interesting source for palaeoenvironmental and palaeoclimatological data. Especially, comparison of palaeoclimatic records of islands lying south and north of the Polar Frontal Zone can provide information on its role in the Earth's climate system.

Until now, the best studied sub-Antarctic island is South Georgia (south of the PFZ).

Geochemical and geophysical, geomorphological and palaeobotanical proxy data exist for this island. Palynology, the most used palaeobotanical method gives only restricted palaeoecological and climatological information on South Georgia ([Barrow and LewisSmith, 1983] and [Van der Putten et al., 2004] and references therein). Macrofossil analysis on Holocene organic sediment cores, however, produced data that could be interpreted in terms of environmental and climatic changes ([Van der Putten et al., 2004] and [Van der Putten et al., in press]). Macrofossil analysis, in contrast to pollen analysis, records changes of both phanerogam and moss vegetation, the latter being one of the major components of the present-day plant communities of sub-Antarctic islands. Many bryophyte species occupy restricted ecological niches, are sensitive to ecological and climatic change, and can, therefore, be extremely useful indicators for environmental reconstruction (Jonsgard and Birks, 1995).

This paper aims to reconstruct the palaeoenvironmental and palaeoclimatological history of the last 6200 years of the sub-Antarctic Ile de la Possession, Iles Crozet (north of the PFZ) in the Southern Indian Ocean, based on a multi-proxy record of a peat sequence. The methods applied are macrobotanical and diatom analyses, and geochemical and rock magnetic measurements. The chronology of the core is based on radiocarbon dating.

\section{The site investigated}

Land in the sub-Antarctic region is restricted to six islands or island groups, dispersed in the vast circum-Antarctic Southern Ocean: South Georgia, the Prince Edward Islands, Iles Crozet, Iles Kerguelen, the Heard Island group and Macquarie Island (Fig. 1). Due to their geographic location, all of them are exposed to a cool oceanic climate. Islands south of the PFZ (South Georgia and the Heard Island group) have a harsher climate compared to the others, which is expressed by the presence of permanent ice, covering more than $50 \%$ of their area. A generally depauperate flora and tundra-like vegetation devoid of trees is typical. Bryophytes are a major component of sub-Antarctic plant communities.

The climatic conditions are very suitable for peat formation, and an extensive peat cover has developed on these islands at low altitudes. 
The Iles Crozet are located in the sub-Antarctic part of the Indian Ocean between $46^{\circ}$ and $46^{\circ} 30^{\prime} \mathrm{S}$ and $50^{\circ}$ and $52^{\circ} 30^{\prime} \mathrm{E}$. They comprise five islands or island groups distributed from the West to the East: Ile aux Cochons, Ile des Pingouins, Ilots des Apôtres, Ile de la Possession and Ile de l'Est. A scientific station was established in 1962 on Ile de la Possession $\left(46^{\circ} 25^{\prime} \mathrm{S}-51^{\circ} 45 \mathrm{E}\right)$ which is by far the best-studied island of the archipelago.

Ile de la Possession has a surface of ca. $146 \mathrm{~km}^{2}$ and culminates at the Pic du Mascarin (934 $\mathrm{m}$ a.s.1.) (Fig. 1). The island can be divided into two parts. The eastern part is characterised by several plateaus intercepted by huge valleys (Vallée des Branloires, Baie de la Hébé, Baie du Petit Caporal) with steep slopes, probably of glacial origin (Chevallier, 1981). The western part of Ile de la Possession has a more mountainous topography. The littoral is mainly formed by steep cliffs although some coastal plains are present at the end of valleys (Baie du Marin, Baie Américaine, Baie de la Hébé) in the eastern part of the island.

The climate of Ile de la Possession can be described as cool oceanic with strong winds and subject to rapid changes. The mean annual temperature is $+5^{\circ} \mathrm{C}$ and seasonal variation is very small (mean temperature of the coldest month is $+2.9^{\circ} \mathrm{C}$ and this of the warmest month is $\left.+7.9^{\circ} \mathrm{C}\right)$ (Frenot, 1986). The annual precipitation is high $(2391 \mathrm{~mm})$ as well as the mean wind velocity $(9.6 \mathrm{~m} / \mathrm{s})$.

The Iles Crozet are of volcanic origin and the age of Ile de la Possession is about 8 myr (Giret, 1987). The volcanic history of the island is complex and can be summarized in five phases (Chevallier, 1981). The most recent phase $\mathrm{V}$ is characterised by a strombolian type of volcanism. Several small red cones were formed (Mont des Cratères, Mont Branca, Morne Rouge etc.), which are dispersed over the island and which are supposed to be very recent (5000 to 10,000 yr BP) (Chevallier, 1981).

Field surveys and radiocarbon dating (some dates are reported in this paper) provide evidence that volcanic activity terminated before $5800{ }^{14} \mathrm{C}$ yr BP. One of the cones of the volcanic phase V, the Morne Rouge (116 m above sea level), is situated at the exit of the huge Ushaped Vallée des Branloires (Fig. 1), more or less in the middle of the transverse coastal profile of the valley. A small lake (maximum water depth is $4 \mathrm{~m}$ ) has formed in the crater of this volcano at an altitude of approximately $50 \mathrm{~m}$ above sea level (Fig. 2). The north-eastern crater rim is steep and descends nearly directly into the lake. Only a very narrow stony shore is present. On the south-western part, the lake is bordered by a mire, approximately $30 \mathrm{~m}$ wide.

\section{Methods}

\subsection{Fieldwork}

A geomorphological survey was carried out in Vallée des Branloires and the thickness of the peat cover was determined with a hand coring equipment. In the Morne Rouge crater, coring has been done in the swampy mire near the lake as well as in the lake itself (Fig. 2). To check the thickness and the nature of the lake sediments and to sample the base of the lake infilling for radiocarbon dating, coring has been done from a raft, using the same hand coring equipment as before. The peat sequence near the lake was sampled by drilling in two $11 \mathrm{~cm}$ and one $7 \mathrm{~cm}$ diameter PVC tubes. 


\subsection{Sediment stratigraphy, rockmagnetic and geochemical analyses}

In the laboratory, the tubes were split into two halves and the cores were described. Before subsampling, the magnetic low field volume susceptibility (MS) was measured at $2 \mathrm{~cm}$ intervals, using a Bartington ${ }^{\circledR}$ MS2 susceptibility meter connected to a MS2E1 contact probe having a sensitivity of $\pm 1.10^{-5}$ SI unit and a spatial resolution of $\sim 1.5 \mathrm{~cm}$.

Susceptibility measurements were complemented by hysteresis measurements of selected peat and pure scoriae samples performed in a rotation magnetometer ([Burov et al., 1986] and [Jasonov et al., 1998]) aiding the interpretation of the magnetic susceptibility variations.

The weight of the minerogenic material present in 20 peat samples dispersed over the core (except for the lowest meter as there was not enough sediment left), was determined by loss on ignition (LOI). Slices of $1 \mathrm{~cm}$ thickness were cut out and the volume of each sample was measured by water displacement in order to obtain an identical volume for all the samples. Samples were dried overnight $\left(110^{\circ} \mathrm{C}\right)$ in an air-circulation oven, cooled and the temperature was increased slowly to $550^{\circ} \mathrm{C}$ and then heated for $4 \mathrm{~h}$.

Samples for geochemical analysis (Rock-Eval6 analysis, RE6) were taken every $5 \mathrm{~cm}$. A total of 105 samples was dried overnight in an oven at $40{ }^{\circ} \mathrm{C}$ and then pulverised. The samples had a dry weight between 0.5 and $2.5 \mathrm{~g}$. The pyrolysis program starts with an isothermal stage of $2 \mathrm{~min}$ at $200{ }^{\circ} \mathrm{C}$. Then, the pyrolysis oven temperature was raised at $30^{\circ} \mathrm{C} / \mathrm{min}$ to $650{ }^{\circ} \mathrm{C}$, and held for $3 \mathrm{~min}$ at this temperature. The oxidation phase, performed in a second oven under an air stream, starts at an isothermal stage at $400{ }^{\circ} \mathrm{C}$, followed by an increase to $850{ }^{\circ} \mathrm{C}$ at $30{ }^{\circ} \mathrm{C} / \mathrm{min}$ and held at final temperature for $5 \mathrm{~min}$ (Jacob et al., 2004).

Rock-Eval parameters are described by Espitalié et al. (1977) and specific parameters provided by the new RE6 by Lafargue et al. (1998).

\subsection{Radiometric dating}

Five samples for $\mathrm{AMS}{ }^{14} \mathrm{C}$ dating of the Morne Rouge peat sequence were taken from the residues of counted samples of the macrofossil analysis, taking into account the macrofossil stratigraphy. Two additional bulk samples were sent to date the base of the two cores from the lake (Fig. 2). Samples were pre-treated by routine acid alkali acid (AAA) method and AMS targets were prepared by routine methods (van Strydonck and van der Borg, 1990-1991) at the Royal Institute for Cultural Heritage (Brussels, Belgium). The KIA samples were measured at the laboratory of Leibniz-Labor für Altersbestimmung und Isotopenforschung (Kiel, Germany). The NZA sample was measured at the Rafter Radiocarbon Laboratory (Lower Hutt, New Zealand).

Calibration of radiocarbon dates was performed using the Calib ver. 5.0.1 program (Stuiver and Reimer, 1993) and the Southern Hemisphere calibration dataset (McCormac et al., 2004). In order to construct an age-depth model, central point estimates of the calibrated radiocarbon dates were made. As intercept-based methods should be avoided (Telford et al., 2004), a single central point estimate was determined by the median of the probability distribution. An age-depth model (polynomial function of the 4th order) was built. 


\subsection{Macrofossil analysis}

Samples (slices with a thickness of $1 \mathrm{~cm}$ and a volume of $10-20 \mathrm{~cm}^{3}$ ) for macrofossil analysis were generally taken at an interval of ca. $15 \mathrm{~cm}$ except for the basal $85 \mathrm{~cm}$ of the sequence where samples were taken at more irregular distances. A total of 37 samples has been analysed. Each fresh sample was weighed and the volume was determined by immersing the sample in a known volume of water. The samples were heated for five minutes in a $5 \% \mathrm{KOH}$ solution near boiling point ([Grosse-Brauckmann, 1986] and [Wasylikowa, 1986]) and were washed gently through a $250 \mu \mathrm{m}$ mesh sieve. After sieving, the plant macrofossils were stored in a known volume of water (e.g. $200 \mathrm{ml}$ ). In that way, if in a given sample one or more bryophyte species were dominant, a subsample of a known volume could be taken (after stirring) in order to quantify this species ([Janssens, 1983] and [Van der Putten et al., 2004]). The sample material was systematically examined at $15 \times$ magnification using a stereomicroscope. Seeds, fruits, and fragments of mosses were picked out and counted; leaves and branches of mosses were counted separately. When calculating the number of remains of a taxon, branches were given a weight of 5 and leaves a weight of 1 . The species were identified using a microscope at a magnification of $400 \times$. For all samples, the absolute number of each species of seed, fruit or moss was calibrated for a standard sample volume of $10 \mathrm{ml}$.

The bryophyte nomenclature follows Desplanques and Hébrard (1972), Hébrard (1970) and Ochyra (1998); angiosperm nomenclature follows Davies and Greene (1976). All remains are stored at the Geography Department, Ghent University.

All diagrams were constructed using the Tilia Graph (TGView version 2.0.2.) software (Grimm, 2004). The diagrams were zoned, using a constrained cluster analysis (CONISS; Grimm, 1987).

\subsection{Diatom analysis}

Samples for diatom analysis were dried for $24 \mathrm{~h}$ at $90{ }^{\circ} \mathrm{C}$, and approximately $0.1 \mathrm{mg}$ of the dried material was prepared for further analysis. Diatom slides were prepared following the method of Van der Werff (1955). A small sample was treated with $\mathrm{H}_{2} \mathrm{O}_{2}$ and $\mathrm{KMnO}_{4}$ in order to remove all organic material. To speed up the reaction, samples were heated on a boiling plate for a short period. Addition of known quantities of exotic Lycopodium spores permitted total diatom concentration estimates (Stockmarr 1976) expressed as valves per g dry sediment (VGS). Following centrifugation, the resulting clean material was diluted with distilled water avoiding excessive concentrations of diatom valves that might obstruct the counting. Cleaned diatom valves were mounted in Naphrax ${ }^{\circledR}$. In each sample a total of 500 diatom valves was counted on random transects using an Olympus BX51 microscope equipped with Differential Interference Contrast optics. Light micrographs were taken to identify difficult taxa. Samples and slides are stored at the Department of Bryophyta and Thallophyta of the National Botanical Garden of Belgium in Meise.

Identifications and taxonomy were based mainly on (Van de Vijver et al., 2002a) and (Van de Vijver et al., 2004). The ecological information of sub-Antarctic taxa was based on (Van de Vijver and Beyens, 1999a) and (Van de Vijver and Beyens, 1999b) and Van de Vijver et al., (2002b). 


\section{Results}

\subsection{Fieldwork}

A $5.36 \mathrm{~m}$ long peat sequence was retrieved (Fig. 2). The first PVC tube contained $235 \mathrm{~cm}$ of peat (CMR1). In the second one an additional $216 \mathrm{~cm}$ of peat was sampled (CMR2) and the deepest part of the sequence $(85 \mathrm{~cm})$ was sampled with the $7 \mathrm{~cm}$ diameter PVC tube (CMR3), mounted on hand-coring equipment. The total length of the Morne Rouge sequence is $536 \mathrm{~cm}$.

Cores were taken in the deepest part of the lake at about $4 \mathrm{~m}$ of water depth, which is more or less the deepest part of the crater basin. No lacustrine sediments were found, both cores (of $4.20 \mathrm{~m}$ and $3.40 \mathrm{~m}$ length) being entirely composed of peat. The radiocarbon dates obtained for the bases of the cores are reported on Fig. 2 and Table 2. As the ages of these bases point to simultaneous start of peat growth in the whole crater, the $5.36 \mathrm{~m}$ long peat sequence near the lake is the longest and most complete sequence and is therefore the subject of this study.

\subsection{Sediment stratigraphy, rockmagnetic and geochemical analyses}

Although the sequence consists entirely of peat, except for the deepest $6 \mathrm{~cm}$ (organic silt and gravel), differences in colour and structure are visible. The description is presented in Fig. 3 and with the diagrams (Fig. 4, Fig. 5 and Fig. 6). Red small dispersed scoriae are visible along the whole sequence. The scoriae form a distinct layer at a depth between $110-114 \mathrm{~cm}$.

Before describing the results of the magnetic susceptibility and Rock-Eval analyses, we want to remark that at the very base of the sequence, between 530 and $536 \mathrm{~cm}$, the values of all measured parameters diverge considerably, as the sediment consists of organic silt and gravel (Fig. 3). However, in the description we do not consider this single sample as a separate unit.

To facilitate the description of the parameters presented in Fig. 3, units and sub-units are defined. In general, all curves can be subdivided in two major units (except for the hydrogen index (HI) and the TpS2 curves): Unit 1 from 530 to $287 \mathrm{~cm}$ and Unit 2 from 287 to $0 \mathrm{~cm}$ (Fig. 3). Eight sub-units can be recognised, mainly based on the total organic carbon (TOC), the HI and to a lesser extent on the oxygen index (OIRE6) curves. Magnetic susceptibility and geochemical parameters will be described as much as possible in relation to the units and subunits defined here (Fig. 3).

Positive susceptibility values are observed over the entire investigated peat profile, with generally low values in Unit 1 and higher values in Unit 2. Distinct susceptibility peaks occur in both units. The peak susceptibility values are smaller in Unit 1 than in Unit 2 (Fig. 3). Additional rock magnetic measurements on single peat and scoriae samples (Table 1) indicate low paramagnetic contributions in peat while this is not the case for scoriae. The latter have also enhanced magnetic remanence values.

The Rock-Eval parameters represented in this study are the following: (i) Total Organic Carbon (TOC, \%); (ii) Hydrogen Index (HI, in mg HC/g TOC); (iii) Oxygen Index OIRe6 (in $\mathrm{mg} \mathrm{O} / \mathrm{g}$ TOC) and (iv) $\mathrm{TpS} 2\left({ }^{\circ} \mathrm{C}\right)$.

TOC values give the total amount of organic matter (OM) in the sediment sample. Generally, in Unit 1, a relatively high content of OM (between 10 and 30\%) is present while in Unit 2 lower values (between 5 and 15\%) of TOC have been measured. Further subdivision of both 
units in sub-units can be made as indicated with characters from A until $\mathrm{H}$ on Fig. 3. The highest TOC values are present in the lowest part of the core (sub-unit A).

The Hydrogen Index (HI) is the amount of hydrocarbonaceous (HC) products released during pyrolysis normalized to TOC. HI values of $250-350 \mathrm{mg} \mathrm{HC} / \mathrm{g}$ TOC are typical of well preserved higher plant OM (Jacob et al., 2004). The HI varies between 150 and $450 \mathrm{mg} \mathrm{HC/g}$ TOC with mean values around $250 \mathrm{mg} \mathrm{HC} / \mathrm{g}$ TOC. The subdivision into two units is not as obvious with HI as for MS and TOC. However, the same sub-units as in the TOC curve with the same evolution can be recognised in the HI curve, except for sub-unit A where values are lower than in sub-unit B in contradiction with the TOC curve.

The Oxygen Index Rock-eval 6 (OIRe6) is an estimate for the oxygen content of the OM. OIRe 6 varies between 110 and $210 \mathrm{mg} \mathrm{O}_{2} / \mathrm{g}$ TOC. The two principal units are present in the OIRe6 curve with generally lower values in Unit 1 than in Unit 2. The sub-units recognised in the TOC and HI curves are observable in unit 1 but are less pronounced in unit 2.

Opposite trends in the HI and OIRe6 curves are used as a an indicator for the degree of preservation of the OM (e.g. high HI and low OIRe6 point to a good preservation of the OM).

$\mathrm{TpS} 2$ is the temperature measured in the oven at the top of peak S2, which thus corresponds to the maximum release of hydrocarbonaceous products during pyrolysis. TpS2 (and the previous used and directly related parameter Tmax), is a well-known OM maturity indicator in ancient sediments (Espitalié et al., 1985). In recent sediments and soils, TpS2 varies in a step-wise fashion with the degree of OM preservation (Disnar et al., 2003). TpS2 values generally vary between 300 and $470{ }^{\circ} \mathrm{C}$. In the present study they remained around $465{ }^{\circ} \mathrm{C}$ except in a few levels near the base and top of the core where much lower values $\left(\mathrm{ca} .300^{\circ} \mathrm{C}\right.$ ) might denote notable proportions of well preserved labile biopolymers (e.g. carbohydrates; [Disnar et al., 2003] and [Jacob et al., 2004]).

\subsection{Radiometric dating}

Laboratory code-numbers, depths, dates, calibrated ages ( $1 \sigma$ and $2 \sigma$ ranges) and the central point estimates of the dates used in the age-depth model are shown in Table 2. The age-depth model (polynomial function of the 4th order) is represented in Fig. 3 and on the diagrams (Fig. 4 and Fig. 5).

The central point estimates used in the age-depth model were determined by the median of the probability distribution.

\subsection{Macrofossil analysis}

\subsubsection{Vascular plant remains}

Nine different types of macrofossil remains of vascular plants have been identified in the samples. Most of them are seeds except for Azorella selago leaf remains and Montia fontana fruit remains (perianth). All have been identified to species level except for the grass species (Poaceae) and Juncus scheuchzerioides/pusillus. Even after "artificial fossilisation" of modern material, it was not possible to identify the grass seeds to species level. Concerning the Juncus seeds, comparison with reference material suggests they are Juncus scheuchzerioides but the presence of J. pusillus may not be excluded. Further in the text we 
will use Juncus sp. to designate these species. Total phanerogam plant remains for a constant volume of sample $(10 \mathrm{ml})$ are represented on Fig. 5 .

\subsubsection{Mosses}

Eighteen moss taxa have been identified, mostly to species level. Too degraded remains were only identified to genus level (Bryum sp., Campylopus sp. Polytrichum sp. Bucklandiella sp. and Hymenoloma sp.). Sometimes it is necessary to examine the complete moss plant to differentiate between two species, which is never the case in the fossil record. Therefore both possible determinations are given (e.g. Distichophyllum imbricatum/fasciculatum, Polytrichum juniperinum/piliferum, Ditrichum strictum/immersum, Pohlia nutans/mielichhoferia). Total moss remains for a known volume of sample $(10 \mathrm{ml})$ are represented on Fig. 4.

\subsubsection{Zonation}

Vascular plant macroremains and moss remains are presented in two separate diagrams (Fig. 4 and Fig. 5). Zonation of the diagrams is based on a constrained cluster analysis of the moss data. Four main zones can be recognized, characterized by specific species assemblages: zone $1(535-476 \mathrm{~cm})$, zone $2(476-287 \mathrm{~cm})$, zone $3(287-176.5 \mathrm{~cm})$ and zone $4(176.5-100 \mathrm{~cm})$. Zones 2 and 4 are subdivided in three sub-zones.

\subsubsection{Zone $1(535-476 \mathrm{~cm})$}

The first zone, the base of the sequence, is characterised by four moss species: Bryum sp., Breutelia integrifolia, Campylopus sp. and Philonotis tenuis. All four species have their maximal number in zone 1 . No other moss species is present except for a small number of Sanionia uncinata in the top sample. Noteworthy is that no moss remains have been found in the deepest sample $(529 \mathrm{~cm})$ of the sequence.

All higher plant remains encountered in the whole sequence, are present in zone 1 except for Callitriche antarctica and Limosella australe. Azorella selago leaves are very prominent in two samples (519 and $510 \mathrm{~cm}$ ). Montia fontana seems to have its highest occurrence, especially in the three basal samples. In the top sample of zone 1, Juncus sp. and Ranunculus biternatus become more important, while Azorella selago nearly disappears and Montia fontana decreases.

\subsubsection{Zone $2(476-287 \mathrm{~cm})$}

Zone 2 can be subdivided in three sub-zones. This subdivision is rather based on visual examination of both the moss and the phanerogam diagrams, the geochemistry and the MS data, than on the results of the constrained cluster analysis.

In sub-zone $2 \mathrm{a}(476-412.5 \mathrm{~cm})$, the four moss species, characteristic for the first zone, disappear (except for Campylopus sp. which is still abundantly present in the lowest sample of sub-zone 2a). It is generally characterised by a very low number of moss remains. Only in the lowest sample (37), mosses are abundant. Ptychomnium densifolium, Distichophyllum imbricatum/fasciculatum and Bartramia cf. patens occur for the first time in the sequence in this sample, but disappear nearly completely in the samples above. In sub-zone $2 \mathrm{~b}$ (412.5$377.5 \mathrm{~cm})$ Ditrichum conicum and Pohlia wahlenbergii occur. The latter species is only 
present in this sub-zone and Bartramia cf. patens has its highest number here. The species characteristic for zone 1 are also present (Bryum sp., Breutelia integrifolia, Philonotis tenuis). In sub-zone 2c (377.5-287 cm), Bryum sp., Breutelia integrifolia, Philonotis tenuis and Pohlia wahlenbergii disappear. Ptychomnium densifolium, Distichophyllum imbricatum/fasciculatum, Bartramia cf. patens, Sanionia uncinata and Ditrichum conicum, already encountered in the previous sub-zone, are still present. In the samples at a depth of 326 and $310 \mathrm{~cm}$, Polytrichum sp., Polytrichum juniperinum/peliferum and Bucklandiella sp. are present.

The most characteristic vascular plant remains found in zone 2 are seeds of Juncus scheuzerioides/pusillus, with its highest representation in the lowermost sample of this zone. From sub-zone $2 \mathrm{~b}$ on, Azorella selago and Montia fontana occur. Poaceae are present in low quantities in only two samples (464 and $405 \mathrm{~cm})$. One sample $(405 \mathrm{~cm})$ is notably rich in vascular plant species.

\subsubsection{Zone $3(287-176.5 \mathrm{~cm})$}

All moss species typical for zone 2 disappear in zone 3, except for Ptychomnium densifolium. Two species (Bryum sp. and Breutelia integrifolia) abundantly present in the first zone reappear and are important in zone 3. Bucklandiella sp. occurs in two samples (230 and $214 \mathrm{~cm}$ ). Zone 3 is quite rich in vascular plant remains. The first occurrence of Limosella australis happens in zone 3 and in the lower part Azorella selago leaves are abundant and form a second peak in the sequence. Juncus sp. is present in all the samples but the numbers of seeds found are clearly lower than in zone 2 .

\subsubsection{Zone $4(176.5-0 \mathrm{~cm})$}

Zone 4 can be subdivided in three sub-zones.

In the first sample of sub-zone $4 \mathrm{a}(176.5-135 \mathrm{~cm})$ Bryum sp. is still abundantly present but it decreases in the sample above to finally disappear in the top sample of sub-zone 4a. Breutelia integrifolia occurs but in very low quantities throughout this sub-zone. Sub-zone $4 \mathrm{~b}$ (135$101.5 \mathrm{~cm}$ ) is characterised by Ditrichum strictum/immersum which occurs for the first time and by Bucklandiella sp. showing its most important occurrence. Ptychomnium densifolium disappears completely in these two sub-zones. Two vascular plant species are well and constantly represented in sub-zones $4 \mathrm{a}$ and 4b; Azorella selago leaves and fruits and Juncus sp.

In sub-zone 4c $(101.5-0 \mathrm{~cm})$, Bryum sp. and Breutelia intergifolia re-appear and are well represented. Ptychomnium densifolium absent in sub-zones $4 \mathrm{a}$ and $4 \mathrm{~b}$ re-appears as well. Zone $4 \mathrm{c}$ is characterised by the occurrence in some samples and in very low quantities, of a number of species as Ditrichum strictum/immersum, Pohlia nutans/mielichhoferia, Racomitrium lanuginosum and Dicranella hookeri. Bucklandiella sp., although in very low numbers, is present in most of the samples in zone 4c. In this sub-zone the species richness of zone 3 is reinstalled and all vascular plant species are present. Azorella selago and Juncus sp. stay prominent. Montia fontana and Poaceae re-appear while Callitriche antarctica is present in two samples and Limosella australis occurs in four samples. 


\subsection{Diatom analysis}

The diatom diagram can be divided into 3 well-separated zones (Fig. 6).

Zone $1(535-476 \mathrm{~cm})$ is characterised by high concentrations of Psammothidium confusiforme Van de Vijver \& Beyens, Adlafia bryophila (Petersen) Lange-Bertalot and Achnanthidium minutissimum (Kützing) Czarnecki. Other species such as Chamaepinnularia soehrensis var. muscicola (Petersen) Lange-Bertalot \& Krammer are present but only in minor abundances.

Zone $2(476-274.5 \mathrm{~cm})$ starts with a sudden shift in the diatom composition resulting in a short dominance of several Pinnularia species [P. acidicola Van de Vijver \& Le Cohu, $P$. carteri Krammer, $P$. crozetii Van de Vijver \& Le Cohu and $P$. divergentissima (Grunow) Cleve] followed by an overall dominance of Eunotia paludosa Grunow var. paludosa with Chamaepinnularia soehrensis var. muscicola as a subdominant species. Achnanthidium minutissimum, Adlafia bryophila and Psammothidium confusiforme do not disappear entirely but occur at several levels in the core (e.g. around $400 \mathrm{~cm}$ ).

At the beginning of Zone 3 (274.5 cm-top), almost all dominant species of the previous zone disappear completely and are replaced by a more diverse flora with species such as Planothidium aueri (Krasske) Lange-Bertalot, Psammothidium confusiforme, Stauroforma exiguiformis (Lange-Bertalot) Flower, Jones \& Round, Aulacoseira cf. distans (Ehrenberg) Simonsen, Chamaepinnularia evanida (Hustedt) Lange-Bertalot, C. australomediocris (Lange-Bertalot \& Schmidt) Van de Vijver, Adlafia bryophila (Manguin) Van de Vijver and Achnanthidium minutissimum.

\section{Interpretation of the multi-proxy data}

When comparing the zonation of the moss diagram and the diatom diagram, one sees that the boundary between sub-zone $2 \mathrm{c}$ and zone 3 in the moss diagram is located between the samples at a depth of 279 and $295 \mathrm{~cm}(287 \mathrm{~cm} ; 2770 \mathrm{cal} \mathrm{yr} \mathrm{BP})$, whereas the boundary between zone 2 and 3 in the diatom diagram is located between the samples at a depth of 270 and $279 \mathrm{~cm}(274.5 \mathrm{~cm} ; 2600 \mathrm{cal} \mathrm{yr} \mathrm{BP})$. Based on the age-depth model, the time difference between the boundaries is ca. 170 calibrated years.

Taking into account sediment stratigraphy, geochemical and MS data, the cluster analysis constrained zonation of moss data is used in the following discussion.

The terms zone and sub-zone followed by a number (e.g. sub-zone $2 a)$ refer to the zones defined and presented on the moss diagram (Fig. 4) and transposed to the phanerogam macrofossil diagram (Fig. 5) and the diatom diagram (Fig. 6). When unit and sub-unit followed by a character (e.g. sub-unit A) is used, we refer to the divisions of the curves of the geophysical and geochemical analyses presented in Fig. 3. In Fig. 7 the results of all proxydata are summarised.

\subsection{Rockmagnetic analyses}

Wet peat mainly consists of organic material and water, and should hence possess diamagnetic properties (i.e. negative magnetic susceptibilities). This, however, is not the case in the Morne Rouge core; the susceptibility values are positive over the entire section (Fig. 3). The record shows distinctive peaks in samples containing large pieces of scoriae as for 
instance at 100 to $110 \mathrm{~cm}$ depth (cf. Fig. 3). These scoriae contain more magnetic minerals than the peat as reported by the higher magnetisation values in Table 1. It is therefore assumed that small ferrimagnetic grains contained in scoriae pieces, which occur in different size and quantity, cause the general positive susceptibility signal.

The small high-field susceptibility in peat indicates an absence of paramagnetic minerals, such as clay minerals, confirming the absence of pedogenic processes. The enhanced paramagnetic susceptibilities of scoriae samples, however, are possibly due to mafic minerals such as olivine, pyroxenes, which are apparently not affected by the rather acid environmental conditions.

The additional rockmagnetic experiments confirm that the susceptibility signal of the peat sequence is caused by minerogenic input from the surrounding crater slopes and that susceptibility peaks are caused by larger scoriae pieces. Fig. 3 shows that the susceptibility is generally lower between 287 and $535 \mathrm{~cm}$ (Unit 1), which can be explained by a lower input of minerogenic material. This is supported by the weight of the minerogenic material (see Fig. 3) which is also lower between 287 and $535 \mathrm{~cm}$ (Unit 1). However, a higher input of organic matter during the corresponding time interval may have a diluting effect on the susceptibility signal.

\subsection{Palaeoenvironmental history of the Morne Rouge site}

Zone 1 (6200-5560 cal yr BP) is characterised by high numbers of botanical macroremains. The start of plant growth in the Morne Rouge crater was rather diverse. In the lowest sample $(529 \mathrm{~cm})$, only Montia fontana, Poaceae and Ranunculus biternatus were found. No mosses were present. $M$. fontana and $R$. biternatus grow in or on the edges of small pools. One can imagine a micro-relief in the crater with small pools and drier rock outcrops between them. This is consistent with the diatom data. Psammothidium confusiforme and Adlafia bryophila are most abundant on Ile de la Possession today close to the water edge of pools and lakes (Van de Vijver and Gremmen, unpublished data) or even in the first centimetres of the water. From the sample at a depth of $519 \mathrm{~cm}$ the rocky outcrops between the small pools were colonised by Azorella selago and Campylopus sp., which are characteristic of rock outcrops. In the pool depressions, peat formation started with species like Breutelia integrifolia, Philonotis tenuis and Juncus sp. The TOC values (around 30\%) recorded in sub-unit A are the highest for the whole Morne Rouge record. The OM is rather well preserved in the lower part of sub-unit A (HI around $320 \mathrm{mg} \mathrm{HC} / \mathrm{g}$ TOC and OI around $120 \mathrm{O}_{2} / \mathrm{g}$ TOC) but less well preserved in the upper part (HI ca. $230 \mathrm{mg} \mathrm{HC} / \mathrm{g}$ TOC and OI ca. $180 \mathrm{O}_{2} / \mathrm{g}$ TOC). The very high number of macrobotanical remains is probably responsible for the high TOC values. The abundance of Azorella selago leaf remains is especially striking. MS values are the lowest for the whole core, pointing to the presence of low quantities of minerogenic material at the base of the sequence.

Sub-zone 2a (5560-4630 cal yr BP) starts with the presence of Distichophyllum imbricatum/fasciculatum, Campylopus sp., Bartramia cf. patens and Sanionia uncinata (Fig. 4). The former three species are usually found on rock outcrops and ledges, stony ground and wet soil, although they can occasionally occur on peat ([Hébrard, 1970] and [Ochyra, 1998]). At the same time, a change in the composition of the phanerogam vegetation occurred. Juncus sp. became very prominent and has its highest abundance in the lowest sample $(464 \mathrm{~cm})$ of sub-zone 2a. Azorella selago, disappeared from the record as well as Montia fontana and Poaceae. The micro-relief of small pools and rock outcrops was probably completely covered 
by peat at that time. It is striking that no bryophyte remains are present in the fossil record of this sub-zone above $464 \mathrm{~cm}$ (Fig. 4). Two reasons can be proposed for this phenomenon: (i) no mosses were growing on the site at that moment or (ii) the moss remains were not preserved in the peat. However, in sub-unit B (Fig. 3), the low OIRe6 and relatively high HI values indicate well preserved $\mathrm{OM}$ and in consequence, one could conclude that mosses were not present on the site at that time and that the OM was entirely built up by Juncus sp. Probably the absence of mosses is the reason for the lower TOC values in sub-unit B in comparison with sub-unit A, together with the absence of the cushion forming Azorella selago. A sudden rise of the water table in the mire as a result of more precipitation and/or less evapotranspiration could explain the vegetation change in sub-zone $2 \mathrm{a}$ and especially the good preservation of the OM. On the "neighbouring" Marion Island (Gremmen, 1982) a community characterised by the dominance of Juncus scheuchzerioides grows in very wet conditions. Bryophytes play a very minor role in this association which has a very open character. In general, in sub-zone $2 \mathrm{a}$, less $\mathrm{OM}$ is produced than in zone 1 , which is attested by low numbers of macroremains found (Fig. 3). This could point to colder climate conditions, favouring a good preservation of the OM. The peat formation, started in zone 1, resulted in a drastic shift in the diatom composition. Several Pinnularia species, known to prevail in and on peaty soils (Van de Vijver et al., 2002b), became dominant at the beginning of zone 2a. Due to the presumably very acidic conditions caused by the peat formation, Eunotia paludosa var. paludosa quickly started to dominate. This species is known for its ability to tolerate very acidic conditions and hence is typical for wet, peaty soils on Ile de la Possession (Van de Vijver et al., 2002b).

The mosses Distichophyllum imbricatum/fasciculatum, Campylopus sp. and Bartramia cf. patens in the sample at $464 \mathrm{~cm}$ depth were probably brought in by run-off water from the adjacent slopes at the start of this wetter and/or colder period. The relatively restricted presence of Planothidium aueri, Stauroforma exiguiformis and Staurosira pinnata in the diatom diagram can also be seen in this light since these species have never been found coappearing with the peat-preferring diatoms that dominate this period (Van de Vijver et al., 2002a). In the MS curve a small peak at $456 \mathrm{~cm}$ depth, points to an increased in-wash of minerogenic material, which could support this hypothesis. In general MS values are slightly higher in the core from sub-unit B (Fig. 3) on, which could also contribute to the lower TOC values in this sub-unit.

In sub-unit $C$ (Fig. 3), which corresponds well with sub-zone 2b in Fig. 4 and Fig. 5 (4630$4090 \mathrm{cal}$ yr BP), TOC values decrease again and attain their lowest values within unit 1 . At the same time HI values are low and OIRE6 values are high, indicating bad preservation of the OM. The diversity of the flora is higher than in the previous sub-zone and from the plant macrofossil record, one could conclude that the environmental conditions became slightly drier. In the diatom diagram, several species of zone 1 reappear together with Chamaepinnularia australomediocris and reduce the dominance of Eunotia paludosa. The diversity of the flora might be explained by the existence of a bog with ponds or small very wet depressions, and hummocks. Montia fontana, Ranunculus biternatus, Philonotis tenuis and the diatom Achnanthidium minutissimum are associated with these ponds while Breutelia integrifolia, Eunotia paludosa var. paludosa and Chamaepinnularia soehrensis var. muscicola grew in the wet depressions. Ptychomnium densifolium, Bartramia cf. patens, Sanionia uncinata, Pohlia wahlenbergii, Ditrichum conicum and the diatoms Psammothidium confusiforme and Adlafia bryophila would have occupied the drier hummocks in the bog. $D$. conicum and Azorella selago can also be brought in to the bog by run-off water or wind. The slightly drier conditions can be responsible for the lower TOC values and the relatively bad 
OM preservation. The relatively lower TOC values in sub-unit $\mathrm{C}$ can partly be a result of slightly higher MS values.

In sub-unit D (Fig. 3), TOC values increase, but are very fluctuating. The HI and OI are generally higher and lower respectively than in sub-unit $\mathrm{C}$, but show also prominent fluctuations in comparison with the sub-units described before and so preservation of the OM is somewhat better but "unstable". MS values are somewhat lower than in the previous subunit. In sub-zone 2c (4090-2770 cal yr BP) the same species as in sub-zone $2 \mathrm{~b}$ are present except for Bryum sp., Breutelia integrifolia, Poaceae and Ranunculus biternatus. The generally drier conditions in the bog, which have started in sub-zone $2 b$, continue in sub-zone $2 \mathrm{c}$ and are maybe more accentuated. The species associated with bog ponds or very wet depressions (Breutelia integrifolia, Philonotis tenuis, Achnanthidium minutissimum, Psammothidium confusiforme and Ranunculus biternatus) disappear, pointing to the disappearance of the "hollow and hummock" micro-topography. From the macrofossil record it can be concluded that the site was covered by a relatively drier terrestrial moss vegetation with some Juncus sp. In the upper part of sub-zone 2c Polytrichum sp., Polytrichum juniperinum/piliferum point to more acidic conditions on the peat bog. These acidic conditions could explain the somewhat better preservation of the OM in the upper part of subunit D. The increased percentages of Eunotia paludosa and Chamaepinnularia soehrensis var. muscicola confirm these acidic conditions.

In Unit 2, the sub-units registered in the geochemical and magnetic susceptibility parameters and the zones defined in the moss and phanerogam diagrams are less coincident. However, the coincidence of the boundaries between Unit 1 and Unit 2 and between the botanical zones $2 \mathrm{c}$ and 3 is striking. This boundary probably represents a major environmental change in the Morne Rouge record. In general, background MS values are clearly higher in Unit 2 compared to Unit 1, pointing to a higher minerogenic input in Unit 2. As a consequence, the lower TOC values in Unit 2 are probably, as least partly, due to the dilution of the OM by the higher input of minerogenic material (Thouveny et al., 1994). The peaks in the MS curve are due to the presence of scattered scoriae (except at a depth between 110 and $114 \mathrm{~cm}$ where the scoriae are accumulated in a layer) originating from the crater slopes. As the core site is situated in a volcano crater, there are only two ways to explain a higher input of minerogenic material: (i) erosion and transport of sediment by run-off from the crater slopes and (ii) transport of sediment by wind from the crater slopes. In the first hypothesis, one could expect moss species typical for rocky and stony habitats to be found in the macrofossil record, washed into the bog from the adjacent slopes. As this is not the case, a more pronounced wind regime prevailing on the island from ca. $2800 \mathrm{cal}$ yr BP on, seems the most probable explanation.

When looking at the macrofossil record, a clear vegetation change occurs at the transition from zone 2 to zone 3 (2770-1510 cal yr BP). The drier acidic (oligotrophic) species of zone 2 disappear and Bryum sp and Breutelia integrifolia are constantly present, except for two samples (184 and $199 \mathrm{~cm}$ ) and in sub-zone 4b (1150-870 cal yr BP). In the samples at 184 and $199 \mathrm{~cm}$ the two former species are replaced by Ptychomnium densifolium which is also present in sub-zone 4c (870-0 cal yr BP). Juncus sp. still occurs in zones 3 and 4 but in lower quantities than in zone 2. Also Azorella selago is constantly present in both these zones with a second peak in the presence of leaf remains in the lower part of zone 3 . When looking at the MS curve the highest values occur in sub-unit E. When accepting the stronger wind regime hypothesis, the period between ca. 2800 and 2000 cal yr BP was probably characterised by the strongest winds in the whole record. This could explain the greater abundance of $A$. selago as 
this is a typical cushion forming fell-field species, whose growth form is adapted to very strong winds. Another possibility is that $A$. selago was blown into the crater due to the stronger wind regime. Parts of this plant (stems) are regularly found in quite big quantities in insect traps on the island, proving the ability of transport by wind of this species (B. Van de Vijver, pers. comm.). Limosella australis appears for the first time in the sequence in the lower part of zone 3. It is also clearly represented in sub-zones $4 \mathrm{~b}$ and $4 \mathrm{c}$. This species grows in wet conditions, usually on a thin layer of organic mud (Gremmen, 1982). Also $B$. integrifolia and Bryum sp. are species which can indicate more minerotrophic conditions and availability of nutrients in the peat bog (Gremmen, 1982). This is consistent with a higher content of minerogenic material in the Morne Rouge record after ca. $2800 \mathrm{cal}$ yr BP, expressed by generally higher MS values and consequently lower TOC values.

The diatom composition reflects the presence of an open water body near the coring site. Aulacoseira cf. distans, Stauroforma exiguiformis and Staurosira pinnata are typically found nowadays on the sub-Antarctic islands in larger (shallow) pools and small lakes (Van de Vijver et al., 2001). The combination of these aquatic diatoms with more bryophilic species such as Chamaepinnularia evanida, C. australomediocris and Planothidium aueri may indicate that the exact location of the waterbody did not entirely coincide with the coring site, but was situated at a certain distance, with lake water flooding the site from time to time. The presence of Aulacoseira cf. distans, frequently reported as an indicator for continuous mixing of the water column, can confirm the idea of increased wind activity. Adlafia bryophila,

Achnanthidium minutissum and Psammothidium confusiforme regain a subdominant position which may point to the fact that the open water body was surrounded by moss vegetation as was the case in the earliest samples of this core.

As already mentioned above, sub-zone $4 \mathrm{~b}$ can be distinguished by the absence of Bryum sp. and Breutelia integrifolia and the presence of Bucklandiella sp. and Ditrichum strictum/immersum. This sub-zone is also characterised by the presence of a scoriae layer which coincides with a broad peak in the MS curve. TOC values are very low in sub-zone $4 \mathrm{~b}$ and especially in the upper part of this sub-zone, consistent with the scoriae layer, HI values are low and OIRE6 values are higher than $200 \mathrm{mg} \mathrm{O} / \mathrm{g}$ TOC pointing to a bad preservation of the OM. This is also supported by TpS2 values which attain their highest values for the whole record $\left(>470{ }^{\circ} \mathrm{C}\right)$. Superimposed on the stronger wind regime, a wet event could have occurred roughly between 1150 and $870 \mathrm{cal}$ yr BP culminating in the deposition of a scoriae layer around $900 \mathrm{cal} \mathrm{yr} \mathrm{BP.} \mathrm{Stronger} \mathrm{precipitation} \mathrm{could} \mathrm{have} \mathrm{facilitated} \mathrm{slope} \mathrm{erosion} \mathrm{and} \mathrm{the}$ free drainage of coarse scoriae. The presence of Bucklandiella sp. and D. strictum/immersum, characteristic species for rocky habitats, points in the same direction. Within the diatom composition, typical moss-inhabiting species such as P. aueri temporarily disappear and are replaced by a dominance of aquatic species. Diatomella balfouriana, normally growing on dry soils and very dry mosses (Van de Vijver et al., 2002a), presents its highest abundance here. The composition seems to confirm the hypothesis of a wetter event causing more run-off and erosion.

Referring to the cross section of the Morne Rouge crater and the results of the three cores (Fig. 2), one can conclude that the lake was not present from the beginning of the infilling of the crater basin. The maximum coring depth reaches $8.20 \mathrm{~m}$ and the sediment found in the three cores consists of peat, which started to accumulate between ca. 6500 and 6220 calibrated years ago. This means that, initially, the complete crater basin was covered with vegetation during several thousands of years resulting in a peat deposit of a considerable thickness. The Morne Rouge crater (and consequently also the lake present nowadays) is a 
closed basin without any inlet or outlet and the water balance depends entirely on precipitation and evaporation. The question can be asked why and when the lake was formed. One hypothesis could involve the onset of the stronger wind regime at ca. $2800 \mathrm{cal} \mathrm{yr} \mathrm{BP.} \mathrm{At}$ that time, diatom species characteristic of open water bodies start to occur in the Morne Rouge record, in combination with more bryophilic species, pointing to the presence of a lake near the coring site. Field survey on the island, and especially in the Vallée des Branloires (Fig. 1) where many "lakes" are present, revealed that all of them are formed by wind erosion of the vegetation and underlying peat deposits due to the strong winds on the island. As the ground water table is at or nearly at the soil surface, open water bodies come into existence which can persist as no vegetation is present on the island able to overgrow and fill in a water body, an ecological phenomenon well known in the Northern Hemisphere. The difference in depth where the start of the stronger wind regime is situated in the peat core $(287 \mathrm{~cm})$ and the water depth in the middle of the lake (ca. $4 \mathrm{~m}$ ) gives a difference of more than $1 \mathrm{~m}$, which can be explained by supposing erosion of the peat surface when the lake was formed. The lake was bordered by a peat bog which continued growing and accumulating, resulting in a lake that shows nowadays a maximum depth of ca. $4 \mathrm{~m}$.

\section{Palaeoclimatic implications}

Based on the multi-proxy data from the Morne Rouge sequence, an attempt can be made to infer climatic changes during the last ca. 6200 years on Ile de la Possession (Iles Crozet) (Fig. 7). The first period, starting at ca. $6200 \mathrm{cal} \mathrm{yr} \mathrm{BP}$ and lasting to ca. $5560 \mathrm{cal} \mathrm{yr} \mathrm{BP}$, is probably a period in which relatively warm climatic conditions prevailed. Biological production (plants and diatoms) was high, resulting in the highest TOC values of the core. At the end of this period, a first major change occurs in the species assemblage of the macrobotanical as well as in the diatom record. Based on the geochemical and magnetic susceptibility data, a clear boundary is present around $5560 \mathrm{cal}$ yr BP. On the one hand, biological production decreases suddenly and mosses are hardly present, especially above the sample at $464 \mathrm{~cm}$. On the other hand, the OM is better preserved in this part of the core (ca. $470-415 \mathrm{~cm}$ ). From a botanical point of view, this change could be interpreted as a phase in an ecological succession, evolving from an open patchy vegetation with the presence of small ponds and rock outcrops, to a wet, acidic closed vegetation on a peaty soil, consisting nearly entirely of Juncus sp. However, taking into account all the proxy data, a hypothesis of a more general environmental change can be proposed in order to explain the sudden shift in all the records. As the sequence was sampled in a volcano crater, forming a "closed" basin, environmental change can be considered as climatic change. A colder period can explain the low biological production and also the good preservation of the OM. The latter can also be achieved by a sudden rise of the water table due to wetter climate.

This cold and/or wet period lasted until ca. 4630 cal yr BP. After that, the moss vegetation redeveloped and biological production increased. Diatom evidence suggests a similar situation, as attested by the presence of Adlafia bryophila and Psammothidium confusiforme, two species preferring wet moss habitats. Between ca. 4630 and 4090 cal yr BP a "hollow and hummock" micro-topography developed at the peat surface, with wetter depressions and drier hummocks. After $4090 \mathrm{cal}$ yr BP the wetter species disappeared and a generally drier, acidic bog came into existence. During these two latter phases, drier and maybe warmer climatic conditions prevailed on the island.

At ca. 2780 cal yr BP, a second major change occurred in the Morne Rouge record, clearly visible in all the proxy data. Macrobotanical remains and diatoms point to wetter conditions 
on the site. However, the most striking feature is perhaps the increase of mineral input (scoriae) and the, at least partly, related TOC decrease. Probably, wetter but above all windier climatic conditions prevailed on the island. As a result of the stronger wind regime starting at $2800 \mathrm{cal}$ yr BP, the lake in the peat bog of the Morne Rouge crater came into existence.

Palaeobotanical studies are rather scarce in the sub-Antarctic. For Ile de la Possession (Iles Crozet) only two studies were published ([Bellair-Roche, 1972] and [van Zinderen Bakker, 1972]). The studied sequences were not or not well enough chronologically constrained to infer a climate history. Maybe one of the best dated palynological studies of the southern Indian Ocean islands was made on the Iles Kerguelen (Young and Schofield, 1973), spanning the last glacial-interglacial transition and the Holocene. At $5000{ }^{14} \mathrm{C}$ yr BP (ca. $5700 \mathrm{cal}$ yr BP), a shift from a warm climate to colder conditions was inferred from the pollen data. Although the Morne Rouge sequence started only at about $6200 \mathrm{cal}$ years ago, a similar shift from a warm to a colder climate seems also to be present in the Morne Rouge record at $5560 \mathrm{cal}$ yr BP. However, taking into consideration the treeless and phanerogam-poor flora of sub-Antarctic islands, it can be questioned whether palynology alone can be used as a climate proxy as Young and Schofield (1973) did (Birks and Birks, 2000; see also Van der Putten, 2008).

Based on radiocarbon dating of organic deposits exposed following the recent (since the 1970's) retreat of the Ampère glacier on Iles Kerguelen, three different periods of glacier retreat, corresponding to warm periods, were defined by Frenot et al. (1997). One occurred at ca. $4600{ }^{14} \mathrm{C}$ yr BP (ca. $5160 \mathrm{cal}$ yr BP). The warm period at $5160 \mathrm{cal}$ yr BP seems not to be consistent with the shift to colder conditions deduced by Young and Schofield (1973) at ca. $5700 \mathrm{cal}$ yr BP and in the Morne Rouge sequence between 5560 and $4630 \mathrm{cal}$ yr BP. Glacier fluctuations however, are not only governed by temperature changes. Hydrological changes are as important in the context of expansion or retreat of glaciers, even without any important temperature change. Changes in glacier expansion can also be inherent in the glacier dynamics itself. Glaciers terminating in lakes or in tidewater for example, are subject to instabilities associated with calving termini (Porter, 2000).

A major widespread climatic change, with possible equivalents in many records from various regions in both hemispheres, is dated to 5600-5000 cal yr BP and corresponds to global cooling and contrasting patterns of hydrological change (Magny and Haas, 2004). Two Holocene marine cores situated near the PFZ, in the South Atlantic Ocean ([Hodell et al., 2001] and [Nielsen et al., 2004]) show a climatic optimum in the first half of the Holocene, after which a neoglacial cooling was registered. In Hodell et al. (2001) the neoglacial started abruptly at 5000 cal yr BP and lasted until 3000 cal yr BP when Sea Surface Temperatures warmed slightly for a period of 1000 calibrated years. Nielsen et al. (2004) concluded from their data that the neoglacial started more gradually at $6000 \mathrm{cal} \mathrm{yr} \mathrm{BP}$ and lasted until $2900 \mathrm{cal}$ yr BP after which a late-Holocene warming occurred. Based on our data, the cool/wet period starting at $5560 \mathrm{cal}$ yr BP, does not last as long as registered in the marine cores. From ca. 4600 cal yr BP slightly drier conditions prevailed on the site and biological production increased, probably pointing to less harsh climatic conditions.

The most striking change in all proxy data in the Morne Rouge record occurs at ca. $2800 \mathrm{cal}$ $\mathrm{yr}$ BP. This date is consistent with the end of the neoglacial in the marine records ([Hodell et al., 2001] and [Nielsen et al., 2004]). However, we were not able to interpret the change in our data as a climatic warming as inferred from the marine data. Windier and wetter conditions, caused by an intensification of the Southern Westerlies, are a more probable scenario to 
explain the proxy record of the Morne Rouge. The late Holocene warming in the marine records of Hodell et al. (2001) and Nielsen et al. (2004) is "exceptional" in comparison with other records in the Southern Ocean. Late Holocene neoglacial cooling, starting somewhere between 3000 and $2400{ }^{14} \mathrm{C}$ yr BP (ca. 3100 and 2350 cal yr BP), has been found in various marine sediment sequences from the Antarctic Peninsula region and the Scotia sea ([Domack et al., 2001], [Yoon et al., 2002] and [Bak et al., 2007]) and also from the Ross Sea (Cunningham et al., 1999). Ingolfsson et al. (1998) reviewed the record on land of the Antarctic continent and concluded that the end of a climatic optimum and a shift to neoglacial readvances occurred around $3000{ }^{14} \mathrm{C}$ yr BP (3100 cal yr BP) on the Antarctic Peninsula and around $2600{ }^{14} \mathrm{C}$ yr BP (2600 cal yr BP) in coastal Victoria Land (Ross sea area). Although the timing of this late Holocene neoglacial in the high southern latitudes seems not to be entirely consistent and precisely dated, a climate change to cold and/or wetter conditions about 2600-2800 cal yr BP is a well known feature in North-West Europe (van Geel and Renssen, 1998). It also seems to be widespread and has been described for several sites outside the North Atlantic region ([van Geel et al., 2000], [Chambers et al., 2007] and [Kroonenberg et al., 2007]) and is consistent with the change to more windy and maybe wetter environmental conditions on Ile de la Possession (Iles Crozet).

Recently, several studies were published on the Holocene history of latitudinal shifts and/or changes in the intensity of the Southern Westerlies in southern South America. Results from a multi-proxy Holocene lake record at $33^{\circ} 50^{\prime} \mathrm{S}$ in Central Chile (Jenny et al., 2002) indicate an arid early to mid-Holocene period (9500-5700 cal yr BP) as a result of a southward deflection of the westerly belt. After $5700 \mathrm{cal}$ yr BP, effective moisture increased progressively and, around $3200 \mathrm{cal} \mathrm{yr} \mathrm{BP}$, modern humid conditions were established related to intensified Westerlies.

Based on a marine sediment core from the Chilean continental slope at $41^{\circ} \mathrm{S}$, Lamy et al. (2001) found generally more arid conditions during the middle Holocene (7700 to 4000 cal yr BP) compared to the late Holocene (4000 to present) as a result of a more poleward located Westerly belt. From 4000 cal yr BP a more stable westerly influence was established. In contrast, Moreno (2004) concluded from a pollen record from a lake core at the same latitude $\left(41^{\circ} 45^{\prime} \mathrm{S}\right)$, that a mid-Holocene cooling occurred, concomitant with an increase in humidity, starting from $7600 \mathrm{cal} \mathrm{yr} \mathrm{BP}$ and lasting until ca. $2900 \mathrm{cal}$ yr BP, brought on by an equatorward shift and/or intensification of the Westerlies. Cooling events were found at 7600,

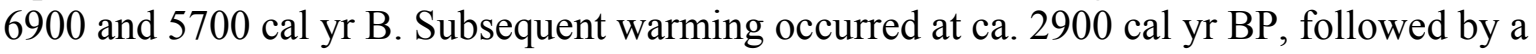
rise in precipitation at $1800 \mathrm{cal} \mathrm{yr} \mathrm{BP.}$

Pollen and charcoal records from a small mire in southern Chile at $51^{\circ} \mathrm{S}$ (Villa-Martinez and Moreno, 2007) are interpreted as indicative of variations in the amount of precipitation of westerly origin. Between 10800 and $6800 \mathrm{cal} \mathrm{yr} \mathrm{BP}$ warm and highly variable moisture conditions occurred due to a highly variable position and/or intensity of the Westerlies. At $6800 \mathrm{cal}$ yr BP a stronger and more stable influence of the Westerlies was established and precipitation increased further in pulses at 5100 and $2400 \mathrm{cal} \mathrm{yr}$ BP.

The picture of the Holocene latitudinal shifts and/or intensification of the Westerlies in southern South America is not straightforward. However, the most striking changes in the Morne Rouge sequence, at ca. 5550 and $2800 \mathrm{cal} \mathrm{yr} \mathrm{BP}$ are consistent with some of the data summarised above. The stronger influence of the Westerlies at $34^{\circ} \mathrm{S}$ deduced from an increase in effective moisture starting at $5700 \mathrm{cal} \mathrm{yr} \mathrm{BP}$, and the establishment of modern humid conditions at 3200 (Jenny et al., 2002) can be tentatively correlated with the results in 
the Morne Rouge sequences. Although in the study of Villa-Martinez and Moreno (2007) a more stable influence was established already at $6800 \mathrm{cal}$ yr BP at $51^{\circ} \mathrm{S}$, precipitation increased further in pulses at 5100 and 2400 cal yr BP.

van Geel et al. (2000) summarised evidence for cooler and more humid conditions in the Andean region, starting at about 2700-2800 cal yr BP, from palynological, palaeolimnological and glacial records. A more equatorward relocation of the Westerlies is assumed in order to explain the increase of effective precipitation at the northern border of the westerly circulation belt. van Geel et al. (2000) suggest that this climate change occurs on a global scale (see also van Geel et al., 1996) probably caused by solar forcing. An intensification of the westerly activity is also found in the Morne Rouge core at c. $2800 \mathrm{cal} \mathrm{yr}$ $\mathrm{BP}$, as proved by a higher input of minerogenic material caused by windier conditions.

On South Georgia (at ca. $55^{\circ} \mathrm{S}$ in the Atlantic Ocean), late Holocene cooler and/or wetter conditions were found in two organic peat deposits from the Stromness Bay/Husvik Harbour area, based on a macrofossil record ([Van der Putten et al., 2004] and [Van der Putten et al., in press]). Although in one sequence a change to wetter conditions was inferred from the sediment stratigraphy of the core around 2800 cal yr BP (Van der Putten et al., 2004) the virtual vegetation change in both cores is dated around 2000 and 2200 cal yr BP ([Van der Putten et al., 2004] and [Van der Putten et al., in press]). Also in the Stromness Bay/Husvik Harbour area (South Georgia), Rosqvist and Schuber (2003) found, based on loss-on-ignition and grey scale density measurements of a lake sequence, a cold period starting at $2400 \mathrm{cal} \mathrm{yr}$ $\mathrm{BP}$ and ending at $1600 \mathrm{cal} \mathrm{yr} \mathrm{BP.} \mathrm{Chronological} \mathrm{control} \mathrm{on} \mathrm{proxy} \mathrm{data} \mathrm{is} \mathrm{a} \mathrm{concern} \mathrm{when}$ comparing the exact timing of oscillations. However, the Morne Rouge sequence as well as both the above mentioned organic sediment cores from South Georgia, are chronologically constrained by radiocarbon dating on moss remains by samples dated just above or under the vegetation change. As samples of a moss peat bank on Elephant Island (Maritime Antarctic) have been found to give some of the most reliable radiocarbon ages in Antarctica ([Björck et al., 1991] and [Ingolfsson et al., 1998]) we consider that the age difference of the late Holocene vegetation change on both islands cannot be assigned to dating errors. When accepting that climate change was the forcing factor for these vegetation changes, we can conclude that, late Holocene palaeoclimate shows an out of phase pattern on South Georgia (between ca. 2200-2000 cal yr BP) and the Iles Crozet (ca. 2800 cal yr BP). As mentioned before, it has been proposed that the Polar Frontal Zone plays an important role as the boundary between Antarctica's climate and that of the rest of the world ([Broecker, 1996], [Bard et al., 1997] and [Domack and Mayewski, 1999]). South Georgia and the Iles Crozet are respectively lying south and north of the PFZ which means that South Georgia shows rather an Antarctic pattern of climate change and the Iles Crozet, a pattern which is consistent with the North Atlantic region. Holocene proxy data supporting this hypothesis are scarce but it can be mentioned that in one of the marine records from the PFZ area (Nielsen et al., 2004), the late Holocene warming (started at $2900 \mathrm{cal} \mathrm{yr} \mathrm{BP}$ ) was interrupted by a fast $4{ }^{\circ} \mathrm{C}$ cooling at 2200 cal yr BP and SST stayed below average until 1600 cal yr BP ("Antarctic type" climate). Based on 11 ice-core deuterium records from the Antarctic, a similar cold oscillation occurred centred at 2000 cal yr BP (Masson et al., 2000).

\section{Conclusions}

The radiocarbon dated, 6200 year old multi-proxy record from Ile de la Possession (Iles Crozet) displays several phases that could be interpreted as ecological and environmental changes which could be tentatively linked to climate change. 
From the start of the peat formation (6200 cal yr BP) until ca. $5550 \mathrm{cal} \mathrm{yr} \mathrm{BP,} \mathrm{biological}$ production was high and climatic conditions must have been relatively warm. At ca. $5550 \mathrm{cal}$ yr BP a shift to low biological production occurred, lasting until ca. 4600 cal yr BP. During this period the organic matter is well preserved, pointing to a cold and/or wet environment. At ca. 4600 cal yr BP, biological production increased again. From ca. $4600 \mathrm{cal} \mathrm{yr} \mathrm{BP}$ until ca. $4100 \mathrm{cal}$ yr BP a "hollow and hummock" micro topography developed at the peat surface, resulting in the presence of a mixture of wetter and drier species in the macrobotanical record. After ca. $4100 \mathrm{cal}$ yr BP, the species of wet habitats disappear and a generally drier, acidic bog came into existence. A major shift in all the proxy data is present at ca. $2800 \mathrm{cal} \mathrm{yr} \mathrm{BP,}$ pointing to wetter and especially windier climatic conditions on the island probably caused by an intensification and/or latitudinal shift of the southern westerly belt. Caused by a stronger wind regime, a lake was formed in the peat deposits of the crater at that time, and it is still present today.

Two major changes in the Morne Rouge record could be linked to widespread climate change: a shift to colder/wetter conditions at ca. 5550 cal yr BP corresponds with global cooling (Magny and Haas, 2004); a shift to a wetter and windier climate occurring around $2800 \mathrm{cal} \mathrm{yr}$ BP can be linked to a widespread climate change (cold and/or wetter conditions) at about 2600-2800 cal yr BP (van Geel et al., 2000). The latter Late Holocene climate change shows an out of phase pattern on South Georgia (between ca. 2200-2000 cal yr BP) and the Iles Crozet (ca. 2800 cal yr BP).

\section{Acknowledgements}

This research was made possible thanks to the logistic and financial support of the French Polar Institute (Programme IPEV 136) and the CNRS (Zone atelier de recherches sur l'environnement antarctique et subantarctique). The technical and practical help in the field of Christopher Swan was indispensable. We thank Nicole Vindevogel and Veerle Vandenhende for the LOI analysis. Funding was provided by FWO-Flanders (Programs 1.5.655-94 and G.0203-97) and Ghent University (BOF-0111 2005). We also thank two anonymous reviewers for their very valuable comments on the manuscript.

\section{References}

Bak et al., 2007 Y.-S. Bak, K.C. Yoo, H.I. Yoon, J.-D. Lee and H. Yun, Diatom evidence for Holocene paleoclimatic change in the South Scotia Sea, West Antarctica, Geosciences Journal 11 (1) (2007), pp. 11-22.

Bard et al., 1997 E. Bard, F. Rostek and C. Sonzogni, Interhemispheric synchrony of the last deglaciation inferred from alkenone palaeothermometry, Nature 385 (1997), pp. 707-710.

Barrow and Lewis-Smith, 1983 C.J. Barrow and R.I. Lewis-Smith, Palynological studies in South Georgia: II. Two profiles in Sphagnum Valley, Cumberland West Bay, British Antarctic Survey Bulletin 58 (1983), pp. 15-42.

Bellair-Roche, 1972 N. Bellair-Roche, Palynological study of a bog in Vallée des Branloires, Ile de la Possession, Iles Crozet. In: R.J. Adie, Editor, Antarctic Geology and Geophysics, Universitetsforlaget, Oslo (1972), pp. 831-834. 
Birks and Birks, 2000 H.H. Birks and H.J.B. Birks, Future uses of pollen analysis must include plant macrofossils, Journal of Biogeography 27 (2000), pp. 31-35.

Björck et al., 1991 S. Björck, N. Malmer, C. Hjort, P. Sandgren, O. Ingolfsson, B. Wallén, R.I.L. Smith and B.L. Jonsson, Stratigraphic and palaeoclimate studies of a 5500-year-old moss bank on Elephant Island, Antarctica, Arctic and Alpine Research 23 (4) (1991), pp. 361374.

Blunier and Brook, 2001 T. Blunier and E.J. Brook, Timing of millennial-scale climate change in Antarctica and Greenland during the last glacial period, Science 291 (5501) (2001), pp. 109-112.

Blunier et al., 1998 T. Blunier, J. Chappellaz, J. Schwander, A. Dallenbach, B. Stauffer, T.F. Stocker, D. Raynaud, J. Jouzel, H.B. Clausen, C.U. Hammer and S.J. Johnsen, Asynchrony of Antarctic and Greenland climate change during the last glacial period, Nature 394 (6695) (1998), pp. 739-743.

Bond et al., 1993 G. Bond, W. Broecker, S. Johnsen, J. McManus, L. Labeyrie, J. Jouzel and G. Bonani, Correlations between climate records from North-Atlantic Sediments and Greenland Ice, Nature 365 (6442) (1993), pp. 143-147.

Broecker, 1996 W. Broecker, Paleoclimatology, Geotimes 41 (1996), pp. 40-41.

Burov et al., 1986 B.V. Burov, D.K. Nourgaliev and P.G. Jasonov, Palaeomagnetic Analysis, Kazan University Press, Kazan (1986) (in Russian).

Chambers et al., 2007 F.M. Chambers, D. Mauquoy, S.A. Brain, M. Blaauw and J.R.G. Daniell, Globally synchronous climate change 2800 years ago: proxy data from peat in South America, Earth and Planetary Science Letters 253 (2007), pp. 439-444.

Chevallier, $1981 \mathrm{~L}$. Chevallier, Notice de la carte géologique au 1: $50000^{\mathrm{e}}$ de l'Ile de la Possession, Iles Crozet, océan Austral, Comité National Français de Recherches Antarctiques 50 (1981), pp. 1-16.

Cunningham et al., 1999 W.L. Cunningham, A. Leventer, J.T. Andrews, A.E. Jennings and K.J. Licht, Late Pleistocene-Holocene marine conditions in the Ross Sea, Antarctica: evidence from the diatom record, The Holocene 9 (2) (1999), pp. 129-139.

Davies and Greene, 1976 L. Davies and S.W. Greene, Notes sur la végétation de l'Ile de la Possession (archipel Crozet), Comité National Français de Recherches Antarctiques 41 (1976), pp. 1-20.

Denton et al., 1999 G.H. Denton, C.J. Heusser, T.V. Lowell, P.I. Moreno, B.G. Andersen, L.E. Heusser, C. Schluchter and D.R. Marchant, Interhemispheric linkage of paleoclimate during the last glaciation, Geografiska Annaler Series A-Physical Geography 81A (2) (1999), pp. 107-153.

Desplanques and Hébrard, 1972 A. Desplanques and J.P. Hébrard, Complément à l'étude des muscinées recoltées aux Iles Kerguelen et Crozet (Campagne d'été des T.A.A.F. 1969) et notes pédologiques, Rivièra Scientifique 3 (1972), pp. 59-76. 
Disnar et al., 2003 J.-R. Disnar, B. Guillet, D. Keravis, C. Di-Giovanni and D. Sebag, Soil organic matter (SOM) characterization by Rock-Eval pyrolysis: scope and limitations, Organic Geochemistry 34 (2003), pp. 327-343.

Domack and Mayewski, 1999 E.W. Domack and P.A. Mayewski, Bi-polar ocean linkages: evidence from late-Holocene Antarctic marine and Greenland ice-core records, The Holocene 9 (2) (1999), pp. 247-251.

Domack et al., 2001 E.W. Domack, A. Leventer, R.B. Dunbar, F. Taylor, S. Brachfeld, C. Sjunneskog and O.L.S. Party, Chronology of the palmer deep site, Antarctic Peninsula: a Holocene palaeoenvironmental reference for the circum-Antarctic, The Holocene, 11 (1) (2001), pp. 1-9.

Espitalié et al., 1977 J. Espitalié, J.L. Laporte, M. Madec, F. Marquis, P. Leplat, J. Paulet and A. Boutefeu, Méthode rapide de caractérisation des roches mères, de leur potentiel pétrolier et de leur degré d'évolution, Revue de l'Institut Français du Pétrole 32 (1977), pp. 23-42.

Espitalié et al., 1985 J. Espitalié, G. Deroo and F. Marquis, La pyrolyse Rock-Eval et ses applications; première partie, Revue de l'Institut Français du Pétrole 40 (1985), pp. 563-579.

Frenot, 1986 Frenot, Y., 1986. Interactions entre la faune lombricienne et les systèmes édaphiques d'une Ile Subantarctique: Ile de la Possession, archipel Crozet. Ph.D. Thesis, Université de Rennes I, France, 358 pp.

Frenot et al., 1997 Y. Frenot, J.-C. Gloaguen, B. Van de Vijver and L. Beyens, Datation de quelques sédiments tourbeux holocènes et oscillations glaciaires aux Iles Kerguelen, C. R. Acad. Sci. Paris Ecologie 320 (1997), pp. 567-573.

Giret, 1987 A. Giret, Géologie des Terres Australes Françaises, C.N.F.R.A. 58 (1987), pp. 1741 .

Gremmen, 1982 N.J.M. Gremmen, The vegetation of the Subantarctic islands Marion and Prince Edward, Geobotany vol. 3, Dr W. Junk Publishers, The Hague (1982) 149 pp..

Grimm, 1987 E.C. Grimm, CONISS: a FORTRAN 77 program for stratigraphically constrained cluster analysis by the method of incremental sum of squares, Computers and Geosciences 13 (1987), pp. 13-35.

Grimm, 2004 E.C. Grimm, TGView. Illenois State Museum, Research and Collections Center Springfield (2004).

Grosse-Brauckmann, 1986 G. Grosse-Brauckmann, Analysis of vegetative plant macrofossils. In: B.E. Berglund, Editor, Handbook of Holocene palaeoecology and palaeohydrology, Wiley, Chichester (1986), pp. 591-618.

Hébrard, 1970 J.P. Hébrard, Muscinées récoltées aux Iles Kerguelen et Crozet pendant la campagne d'été des Terres Australes et Antarctiques Françaises (1969), Revue Bryologique et Lichénologique 37 (1) (1970), pp. 135-162. 
Hodell et al., 2001 D.A. Hodell, S.L. Kanfoush, A. Shemesh, X. Crosta, C.D. Charles and T.P. Guilderson, Abrupt cooling of Antarctic surface waters and sea ice expansion in the South Atlantic sector of the Southern Ocean at 5000 cal yr B.P, Quaternary Research 56 (2) (2001), pp. 191-198.

Hodgson et al., 2004 D.A. Hodgson, P.T. Doran, D. Roberts and A. McMinn, Palaeolimnological studies from the Antarctic and sub-Antarctic islands. In: R. Pientiz, M.S.V. Douglas and J.P. Smol, Editors, Developments in Palaeoenvironmental Research. Long-term Environmental Change in Arctic and Antarctic Lakes, Springer, Dordrecht (2004), pp. 419474.

Ingolfsson et al., 1998 Ó. Ingolfsson, C. Hjort, P.A. Berkman, S. Björck, E. Colhoun, I.D. Goodwin, B. Hall, K. Hirakawa, M. Melles, P. Möller and M.L. Prentice, Antarctic glacial history since the Last Glacial Maximum: an overview of the record on land, Antarctic Science 10 (1998), pp. 326-344.

Jacob et al., 2004 J. Jacob, J.-R. Disnar, M. Boussafir, A. Sifeddine, B. Turcq and A.L.S. Albuquerque, Major environmental changes recorded by lacustrine sedimentary organic matter since the last glacial maximum near the equator (Lagoa do Caçó, NE Brazil), Palaeogeography, Palaeoclimatology, Palaeoecology 205 (2004), pp. 183-197.

Janssens, 1983 J.A. Janssens, A quantitative method for stratigraphic analysis of bryophytes in Holocene peat, Journal of Ecology 71 (1983), pp. 189-196.

Jasonov et al., 1998 P.G. Jasonov, D.K. Nourgaliev, B.V. Burov and F. Heller, A modernized coercivity spectrometer, Geologica Carpathica 49 (1998), pp. 224-225.

Jenny et al., 2002 B. Jenny, B.L. Valero-Garcés, R. Villa-Martínez, R. Urrutia, M.A. Geyh and H. Veit, Early to Mid-Holocene Aridity in Central Chile and the Southern Westerlies: the Laguna Aculeo record (34 S), Quaternary Research 58 (2002), pp. 160-170.

Jonsgard and Birks, 1995 B. Jonsgard and H.H. Birks, Late-Glacial mosses and environmental reconstructions at Krakenes, western Norway, Lindbergia 20 (1995), pp. 64-82.

Knorr and Lohmann, 2003 G. Knorr and G. Lohmann, Southern Ocean origin for the resumption of Atlantic thermohaline circulation during deglaciation, Nature 424 (2003), pp. $532-536$.

Kroonenberg et al., 2007 S.B. Kroonenberg, G.M. Abdurakhmanov, E.N. Badyukova, K. van der Borg, A. Kalashnikov, N.S. Kasimov, G.I. Rychagov, A.A. Svitoch, H.B. Vonhof and F.P. Wesselingh, Solar-forced 2600 BP and Little Ice Age highstands of the Caspian Sea, Quaternary International 173-174 (2007), pp. 137-143.

Lafargue et al., 1998 E. Lafargue, F. Marquis and D. Pillot, Rock-Eval 6 applications in hydrocarbon exploration, production, and soil contamination studies, Revue de l'Institut Français du Pétrole 53 (4) (1998), pp. 421-437.

Lamy et al., 2001 F. Lamy, D. Hebbeln, U. Rohl and G. Wefer, Holocene rainfall variability in southern Chile: a marine record of latitudinal shifts of the Southern Westerlies, Earth and Planetary Science Letters 185 (3-4) (2001), pp. 369-382. 
Lamy et al., 2002 F. Lamy, C. Rühlemann, D. Hebbeln and G. Wefer, High-and low-latitude climate control on the position of the southern Peru-Chile Current during the Holocene, Paleoceanography 17 (2) (2002), p. 1028.

Magny and Haas, 2004 M. Magny and J.N. Haas, A major widespread climatic change around 5300 cal. yr BP at the time of the Alpine Iceman, Journal of Quaternary Science 19 (5) (2004), pp. 423-430.

Masson et al., 2000 V. Masson, F. Vimeux, J. Jouzel, V. Morgan, M. Delmotte, P. Ciais, C. Hammer, S. Johnsen, V.Y. Lipenkov and E. Mosley-Thompson, Holocene climate variability in Antarctica based on 11 ice-core isotopic records, Quaternary Research 54 (3) (2000), pp. $348-358$.

McCormac et al., 2004 F.G. McCormac, A.G. Hogg, P.G. Blackwell, C.E. Buck, T.F.G. Higham and P.J. Reimer, SHCal04 Southern Hemisphere Calibration 0-11.0 cal kyr BP, Radiocarbon 46 (2004), pp. 1087-1092.

Moreno, 2004 E. Moreno, Millenial-scale climate variability in northwest Patagonia over the last 15,000 yr, Journal of Quaternary Science 19 (1) (2004), pp. 35-47.

Nielsen et al., 2004 S.H.H. Nielsen, N. Koç and X. Crosta, Holocene climate in the Atlantic sector of the Southern Ocean: controlled by insolation or ocean circulation?, Geology 32 (4) (2004), pp. 317-320.

Ochyra, 1998 R. Ochyra, The moss flora of King George Island, Antarctica. W. Szafer Institute of Botany, Polish Academy of Sciences, Cracow (1998) 278 pp..

Porter, 2000 S.C. Porter, Onset of Neoglaciation in the Southern Hemisphere, Journal of Quaternary Science 15 (4) (2000), pp. 395-408.

Rosqvist and Schuber, 2003 G.C. Rosqvist and P. Schuber, Millenial-scale climate changes on South Georgia, Southern Ocean, Quaternary Research 59 (2003), pp. 470-475.

Steig and Alley, 2002 E.J. Steig and R.B. Alley, Phase relationship between Antarctic and Greenland climate records, Annals of Glaciology 35 (2002), pp. 451-456.

Steig et al., 1998 E.J. Steig, E.J. Brook, J.W.C. White, C.M. Sucher, M.L. Bender, S.J. Lehman, D.L. Morse, E.D. Waddington and G.D. Clow, Synchronous climate changes in Antarctica and the North Atlantic, Science 282 (1998), pp. 92-95.

Stuiver and Reimer, 1993 M. Stuiver and P.J. Reimer, Extended ${ }^{14} \mathrm{C}$ data base and revised CALIB $3.0{ }^{14} \mathrm{C}$ age calibration program, Radiocarbon 35 (1993), pp. 215-230.

Stockmarr, 1976 J. Stockmarr, Tablets with spores used in absolute pollen analysis, Pollen \& Spores 13 (4) (1976), pp. 615-621.

Telford et al., 2004 R.J. Telford, E. Heegaard and H.J.B. Birks, The intercept is a poor estimate of a calibrated radiocarbon age, The Holocene 14 (2) (2004), pp. 296-298. 
Thouveny et al., 1994 N. Thouveny, J.-L. de Beaulieu, E. Bonifay, K.M. Creer, J. Guiot, M. Icole, S. Johnsen, J. Jouzel, M. Reille, T. Williams and D. Williamson, Climate variations in Europe over the past $140 \mathrm{kyr}$ deduced from rock magnetism, Nature 371 (1994), pp. 503-506.

Van der Putten, 2008 Van der Putten, N., 2008. Post-glacial palaeoecology and palaeoclimatology in the sub-Antarctic. Ph.D. Thesis, Ghent University, Ghent, Belgium,262 pp.

Van der Putten et al., 2004 N. Van der Putten, H. Stieperaere, C. Verbruggen and R. Ochyra, Holocene palaeoecology and climate history of South Georgia (sub-Antarctic) based on a macrofossil record of bryophytes and seeds, The Holocene 14 (3) (2004), pp. 382-392.

Van der Putten et al., in press Van der Putten, N., Verbruggen, C., Ochyra, R., de Beaulieu, J.L., De Dapper, M., Spassov, S., Hus, J., Thouveny, N., in press. Peat bank growth, Holocene palaeoecology and climate history of South Georgia (sub-Antarctica), based on a botanical macrofossil record. Quaternary Science Reviews.

Van der Werff, 1955 A. Van der Werff, A new method for cleaning and concentrating diatoms and other organisms, Verhandlungen der Internationalen Vereinigung für theoretische und angewandte Limnologie 12 (1955), pp. 276-277.

Van de Vijver and Beyens, 1999a B. Van de Vijver and L. Beyens, Freshwater diatoms from Ile de la Possession (Crozet Archipelago, Subantarctica): an ecological assessment, Polar Biology 22 (1999), pp. 178-188.

Van de Vijver and Beyens, 1999b B. Van de Vijver and L. Beyens, Moss diatom communities from Ile de la Possession. (Crozet, Subantarctica) and their relationship with moisture, Polar Biology 22 (1999), pp. 219-231.

Van de Vijver et al., 2001 B. Van de Vijver, P. Ledeganck and L. Beyens, Habitat preferences in freshwater diatom communities from Kerguelen (TAAF, Subantarctica), Antarctic Science 13 (1) (2001), pp. 28-36.

Van de Vijver et al., 2002a B. Van de Vijver, Y. Frenot and L. Beyens, Freshwater diatoms of Ile de la Possession (Crozet archipelago, sub-Antarctica), Bibliotheca Diatomologica 46 (2002), pp. 1-412.

Van de Vijver et al., 2002b B. Van de Vijver, P. Ledeganck and L. Beyens, Soil diatom communities from Ile de la Possession (Crozet, Subantarctica), Polar Biology 25 (2002), pp. $721-729$.

Van de Vijver et al., 2004 B. Van de Vijver, L. Beyens and H. Lange-Bertalot, The genus Stauroneis in the Arctic and (sub-)Antarctic Regions, Bibliotheca Diatomologica 51 (2004), pp. 1-317.

van Geel and Renssen, 1998 B. van Geel and H. Renssen, Abrupt climate change around 2650 BP in North-West Europe : evidence for climatic teleconnections and a tentative explanation. In: A.S. Issar and N. Brown, Editors, Water, Environment and Society in Times of Climatic Change, Kluwer Academic Publishers, Netherlands (1998), pp. 21-41. 
van Geel et al., 1996 B. van Geel, J. Buurman and H.T. Waterbolk, Archaeological and palaeoecological indications of an abrupt climate change in The Netherlands, and evidence for climatological teleconnections around 2650 BP, Journal of Quaternary Science 11 (6) (1996), pp. $451-460$

van Geel et al., 2000 B. van Geel, C.J. Heusser, H. Renssen and C.J.E. Schuurmans, Climatic change in Chile at around $2700 \mathrm{BP}$ and global evidence for solar forcing : a hypothesis, The Holocene 10 (5) (2000), pp. 659-664

van Strydonck and van den Borg, 1990-1991 M. van Strydonck and K. van den Borg, The construction of a preparation line for AMS-targets at the Royal Institute for Cultural Heritage Brussels, Bulletin Koninklijk Instituut van het Kunstpatrimonium vol. 23 (1990-1991), pp. 228-234.

van Zinderen Bakker, 1972 E.M.S. van Zinderen Bakker, Pollen analysis of peat samples of Holocene age from Ile de la Possession (Crozet Islands, sub-Antarctic). In: E.M.S. van Zinderen Bakker, Editor, Palaeoecology of Africa, the surrounding islands and Antarctica, Balkema, Cape Town (1972), pp. 31-34.

Villa-Martínez and Moreno, 2007 R. Villa-Martínez and P.I. Moreno, Pollen evidence for variations in the southern margin of the westerly winds in SW Patagonia over the last 12,600 years, Quaternary Research 68 (2007), pp. 400-409.

Wasylikowa, 1986 K. Wasylikowa, Analysis of fossil seeds and fruits. In: B.E. Berglund, Editor, Handbook of Holocene palaeoecology and palaeohydrology, Wiley, Chichester (1986), pp. 571-590.

Yoon et al., 2002 H.I. Yoon, B.-K. Park, Y. Kim and C.Y. Kang, Glaciomarine sedimentation and its paleoclimatic implications on the Antarctic Peninsula shelf over the last 15,000 years, Palaeogeography, Palaeoclimatology, Palaeoecology 185 (3-4) (2002), pp. 235-254

Young and Schofield, 1973 S.B. Young and E.K. Schofield, Pollen evidence for Late Quaternary climate changes on Kerguelen Island, Nature 245 (1973), pp. 311-312. 


\section{Figures and Tables}

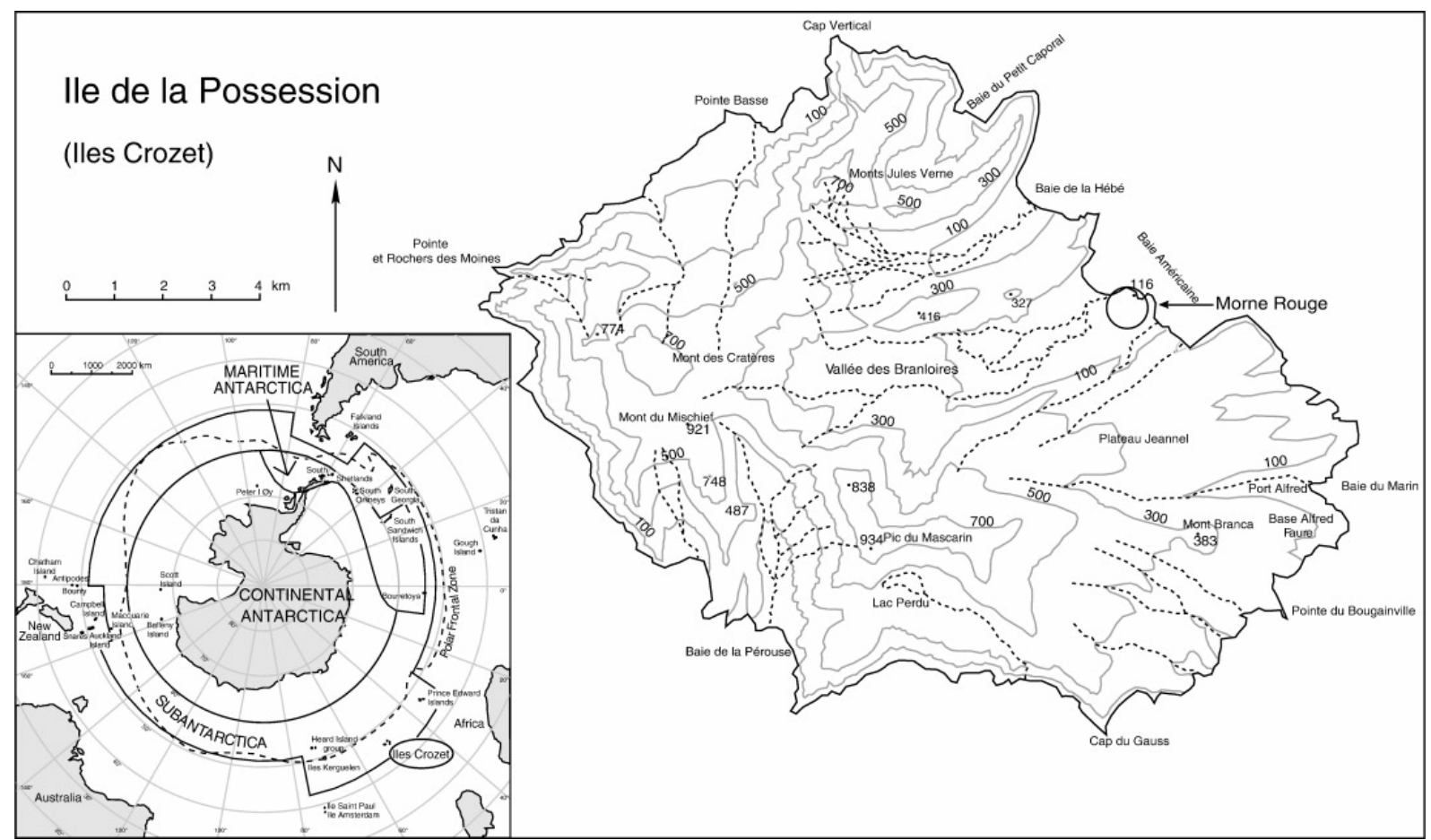

Fig. 1. Map of the mid- and high-southern latitudes with the definition of the sub-Antarctic region and the location of the Polar Frontal Zone. Map of Ile de la Possession (Iles Crozet) and location of the study site.

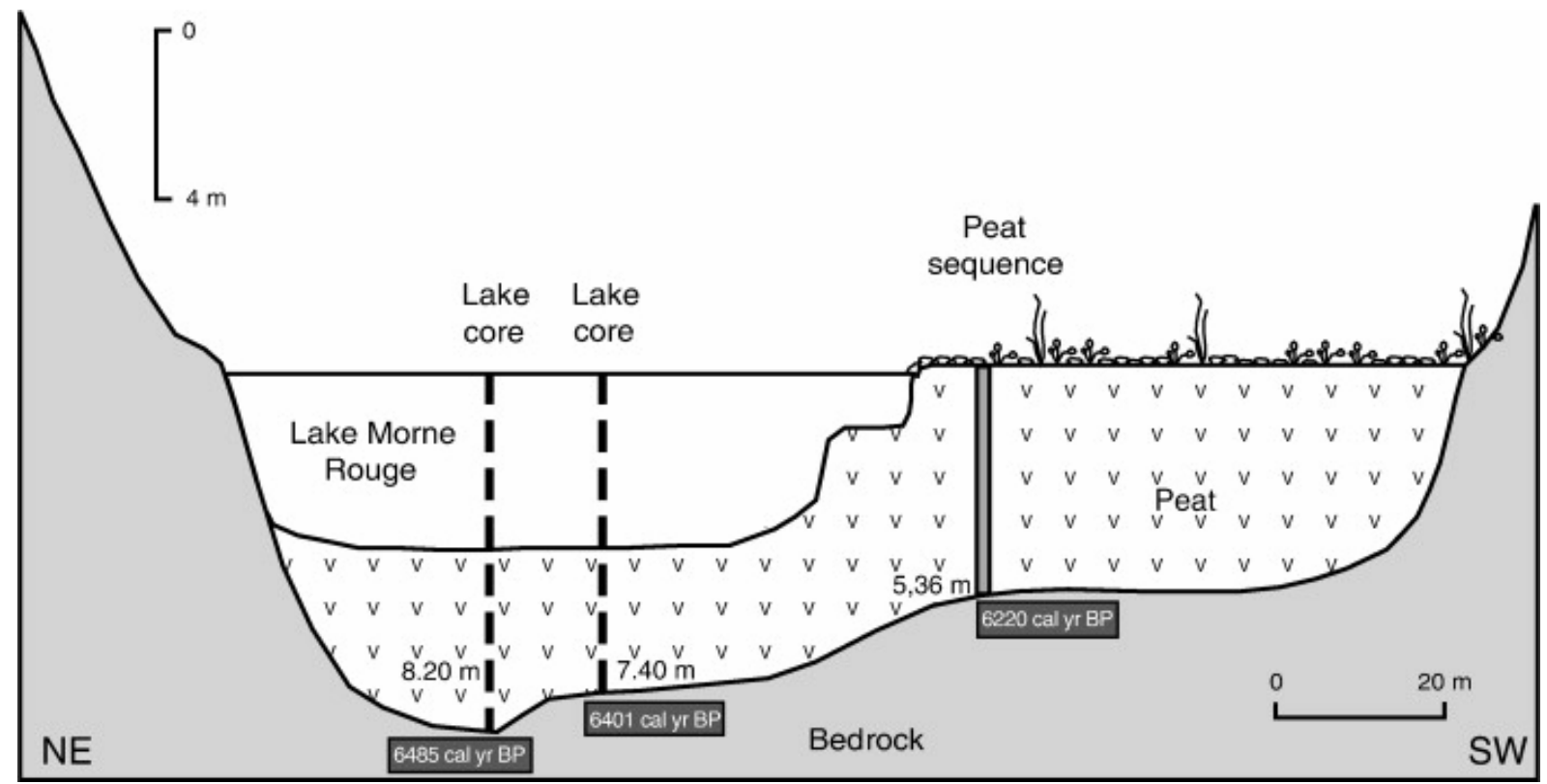

Fig. 2. NE-SW cross-section of the Morne Rouge crater with the location of the Morne Rouge sequence and the two lake cores. Radiocarbon dates of the base of the three cores are indicated. 


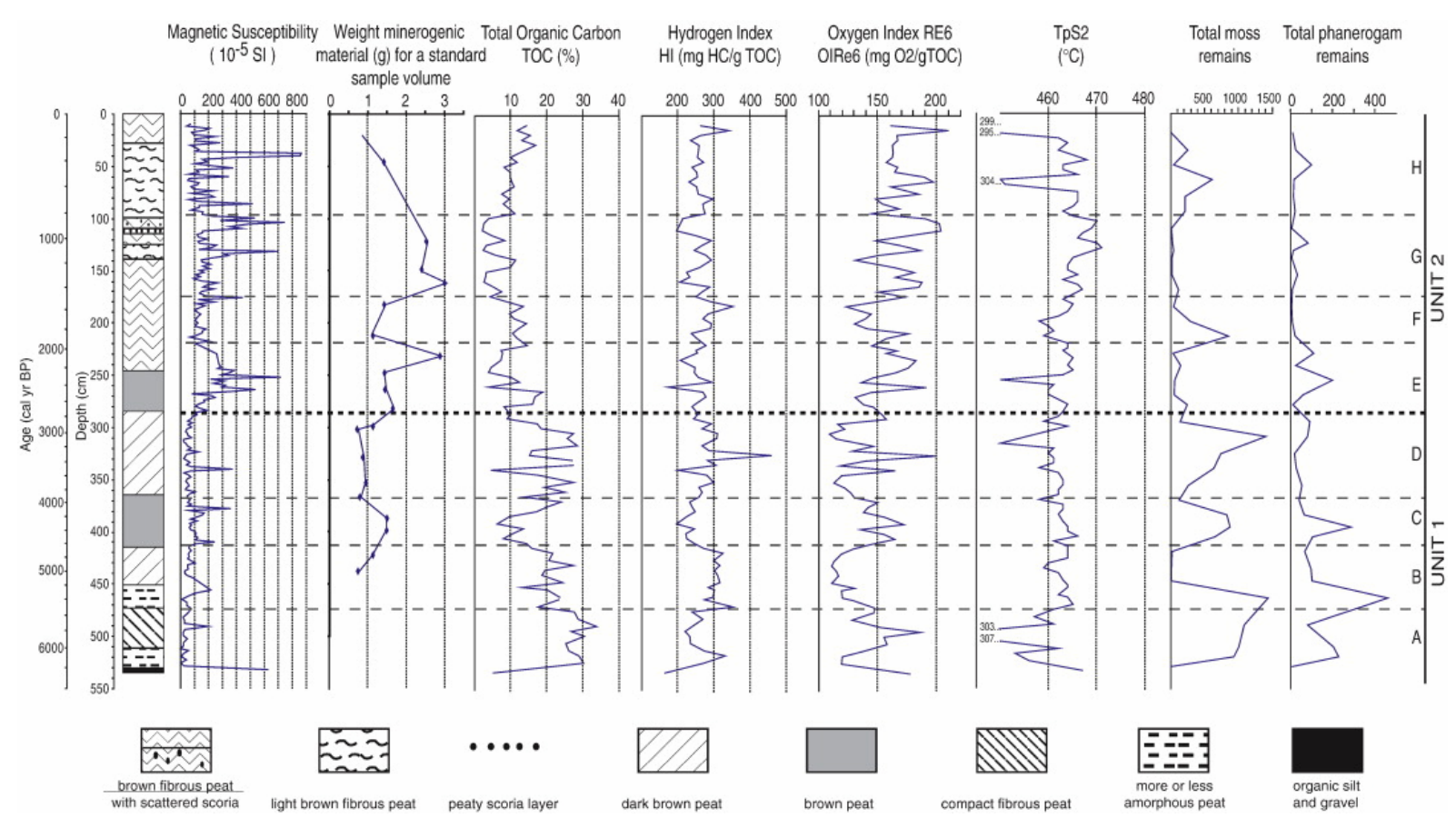

Fig. 3. Sediment stratigraphy, magnetic susceptibility, weight minerogenic material and geochemical data (Rock Eval 6) of the Morne Rouge core, represented on a depth as well as on an age scale. Total moss and phanerogam remains are represented for a known volume of sample $(10 \mathrm{ml})$.

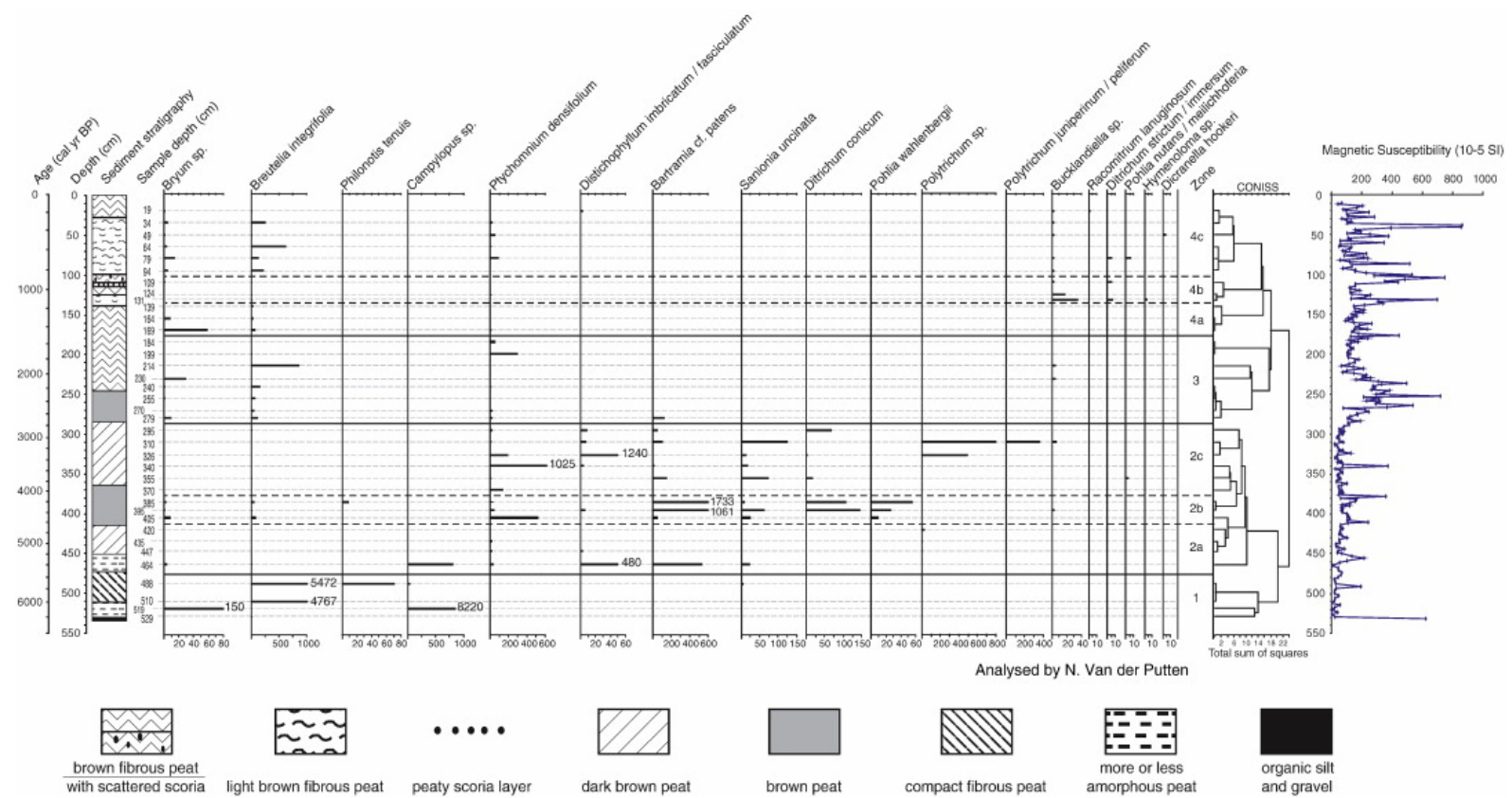

Fig. 4. Bryophyte macrofossil stratigraphy for the Morne Rouge sequence. Note different abundance scales for some species. 

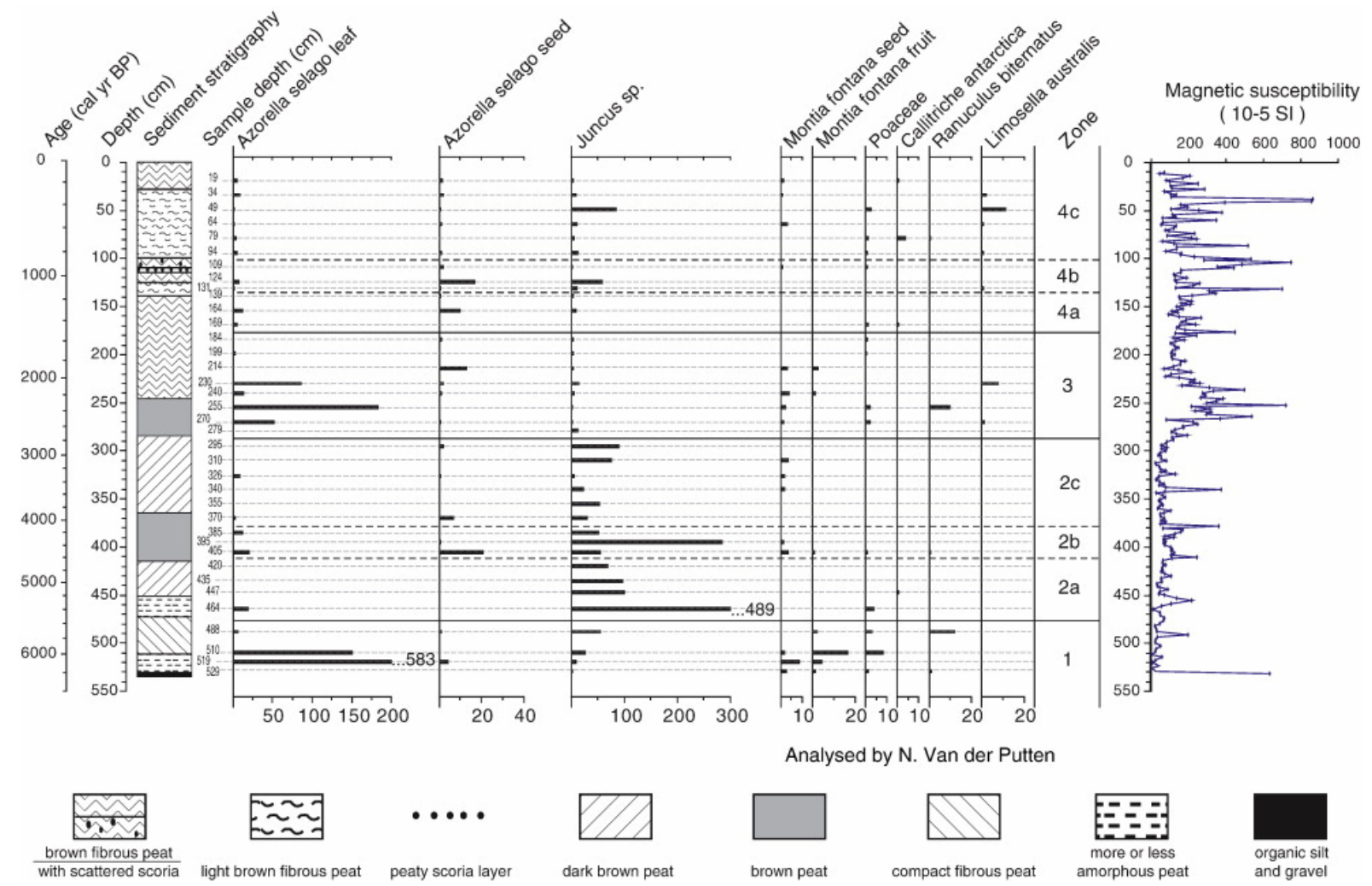

Fig. 5. Phanerogam macrofossil stratigraphy for the Morne Rouge sequence. Note different abundance scales for some species.

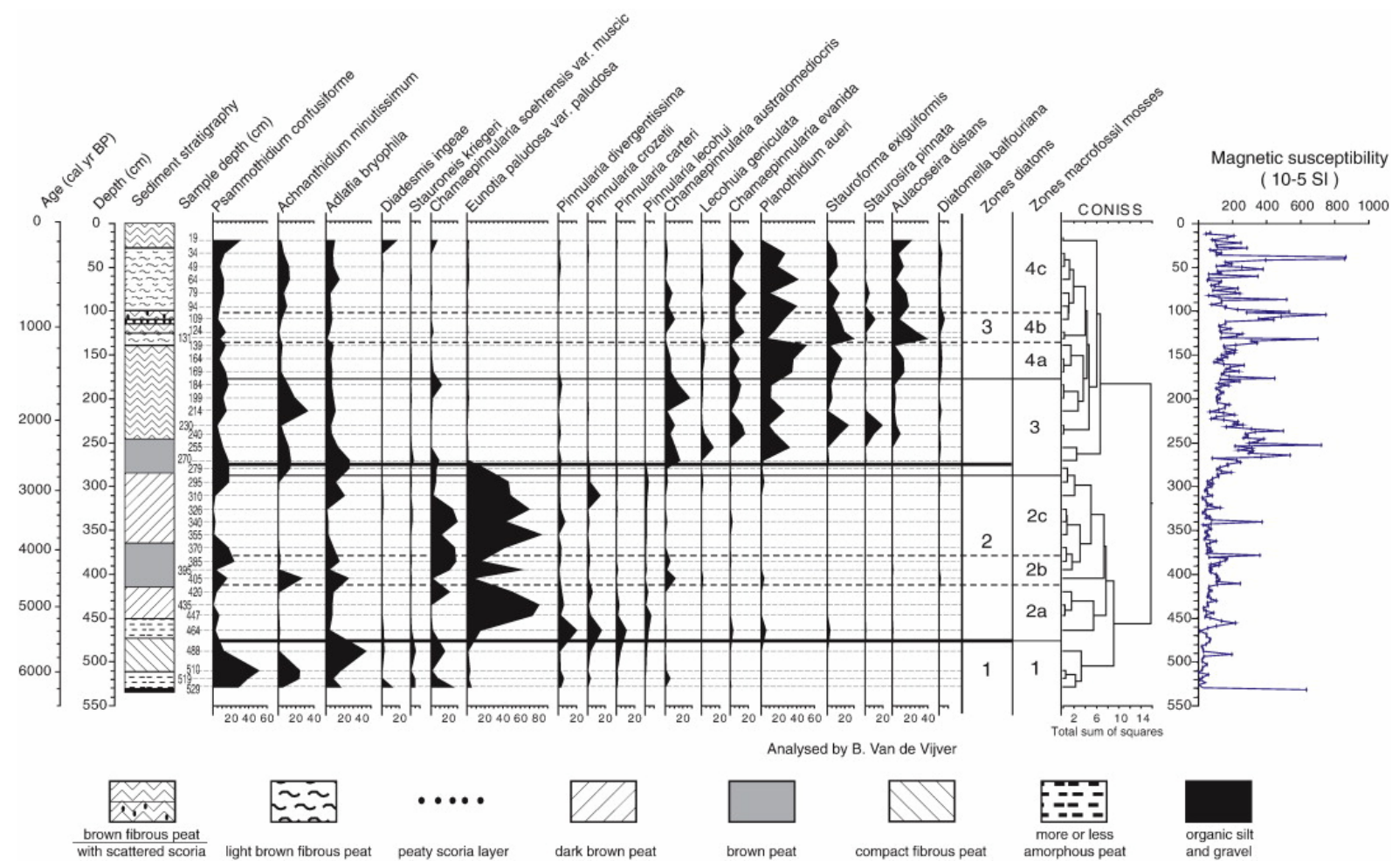

Fig. 6. Diatom stratigraphy for the Morne Rouge sequence. 


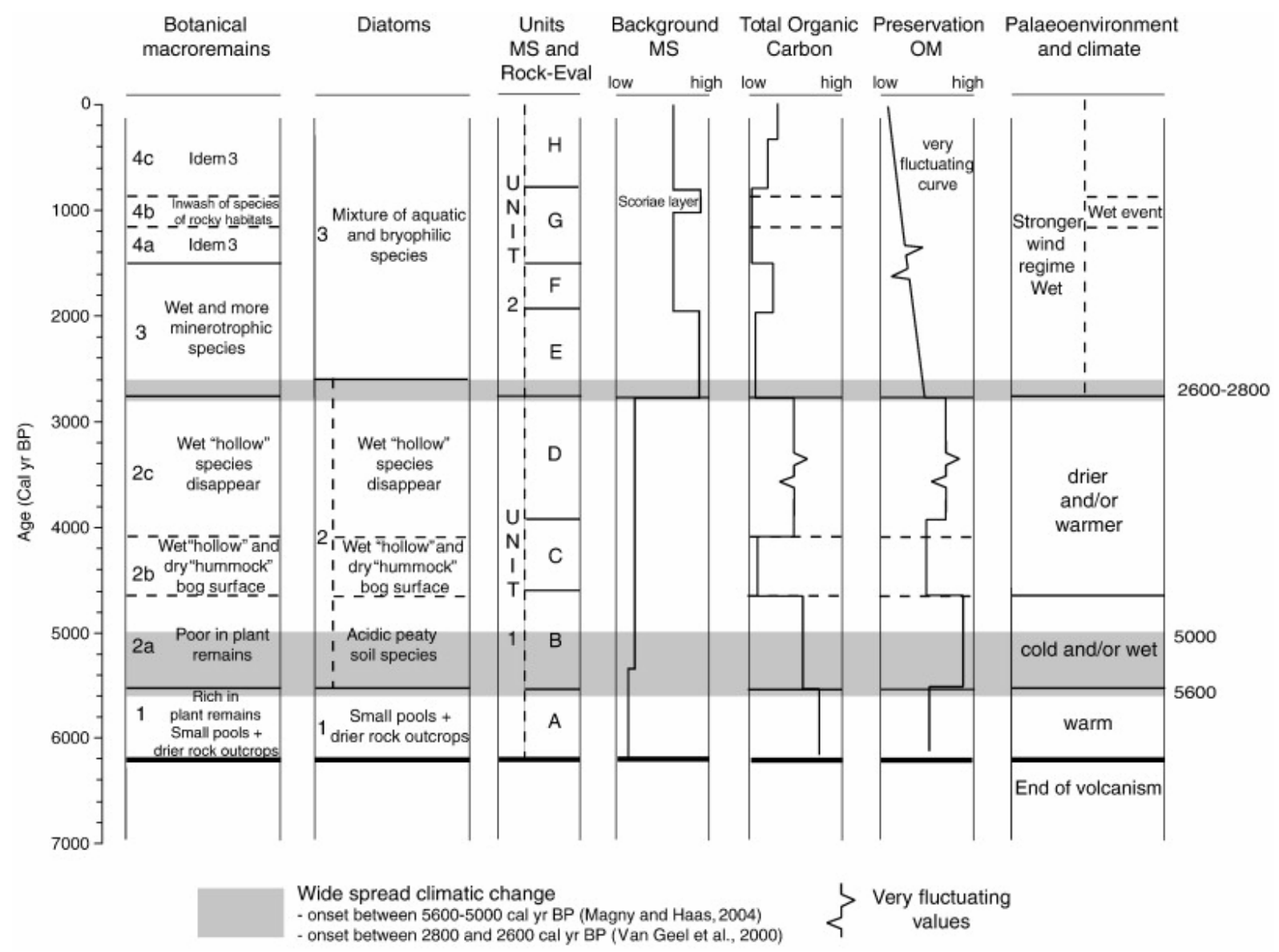

Fig. 7. Summarising schema of the multiproxy record of the Morne Rouge sequence and the resulting reconstruction of the past environmental conditions. 
Table 1. : Rock magnetic parameters of single scoriae and peat samples obtained from hysteresis measurements

\begin{tabular}{|c|c|c|c|c|}
\hline Sample & Depth & Lithology & $\chi_{\text {hifi }}(400$ to $500 \mathrm{mT})$ & $M_{\mathrm{rs}}$ \\
\hline & {$[\mathrm{cm}]$} & & {$\left[10^{-8} \mathrm{~m}^{3} / \mathrm{kg}\right]$} & {$\left[\mathrm{mAm}{ }^{2} / \mathbf{k g}\right]$} \\
\hline $\mathrm{mr} 1-01 \mathrm{~s}$ & 32 & Scoria & 5.4 & 426.1 \\
\hline mr1-06sb & 42 & Scoria & 9.7 & 183.6 \\
\hline mr1-06sr & 42 & Scoria & 10.8 & 121.0 \\
\hline $\mathrm{mr} 1-11 \mathrm{~s}$ & 178 & Scoria & 13.5 & 19.9 \\
\hline $\mathrm{mr} 2-10 \mathrm{~s}$ & 344 & Scoria & 66.3 & 7.2 \\
\hline \multirow[t]{3}{*}{$\mathrm{mr} 2-13 \mathrm{~s}$} & 412 & Scoria & 31.5 & 52.5 \\
\hline & & Mean & 22.9 & 135.1 \\
\hline & & $\pm S t d d e v$ & 9.4 & 64.2 \\
\hline $\mathrm{mr} 1-01 \mathrm{w}$ & 32 & Peat & -0.4 & 22.3 \\
\hline $\mathrm{mr} 1-11 \mathrm{w}$ & 178 & Peat & 1.8 & 5.6 \\
\hline$m r 2-06 w$ & 336 & Peat & 0.5 & 2.8 \\
\hline $\mathrm{mr} 2-10 \mathrm{w}$ & 344 & Peat & 0.6 & 2.6 \\
\hline \multirow[t]{3}{*}{$m r 2-13 w$} & 412 & Peat & 2.6 & 4.0 \\
\hline & & Mean & 1.0 & 7.4 \\
\hline & & $\pm S t d d e v$ & 0.5 & 3.7 \\
\hline
\end{tabular}


Table 2. : Radiocarbon dates for the Morne Rouge sequence

\begin{tabular}{|c|c|c|c|c|}
\hline \multicolumn{5}{|c|}{ Morne Rouge peat sequence } \\
\hline Code & $\begin{array}{l}\text { Depth below } \\
\text { surface }(\mathrm{cm})\end{array}$ & $\begin{array}{l}\text { Radiocarbon date } \\
\text { yr BP }\end{array}$ & $\begin{array}{l}\text { Calibrated date } \\
\text { (BP) }\end{array}$ & $\begin{array}{l}\text { Dates used in age- } \\
\text { depth model }\end{array}$ \\
\hline \multirow{2}{*}{$\begin{array}{l}\text { KIA- } \\
32605\end{array}$} & 64 & $720 \pm 25$ & $1 \sigma 571-663$ & 640 \\
\hline & & & $2 \sigma 564-671$ & \\
\hline \multirow{2}{*}{$\begin{array}{l}\text { KIA- } \\
32602\end{array}$} & 169 & $1510 \pm 25$ & $1 \sigma 1309-1360$ & 1340 \\
\hline & & & $2 \sigma 1301-1391$ & \\
\hline \multirow{2}{*}{$\begin{array}{l}\text { KIA- } \\
32604\end{array}$} & 279 & $2650 \pm 25$ & $1 \sigma 2723-2753$ & 2740 \\
\hline & & & $2 \sigma 2545-2776$ & \\
\hline \multirow{2}{*}{$\begin{array}{l}\text { KIA- } \\
32603\end{array}$} & 405 & $4050 \pm 30$ & $1 \sigma 4421-4516$ & 4480 \\
\hline & & & $2 \sigma 4303-4570$ & \\
\hline \multirow{2}{*}{$\begin{array}{l}\text { NZA- } \\
11509\end{array}$} & 532 & $5480 \pm 60$ & $1 \sigma 6127-6297$ & 6220 \\
\hline & & & $2 \sigma 6000-6316$ & \\
\hline \multicolumn{5}{|c|}{ Morne Rouge lake cores } \\
\hline \multirow{2}{*}{$\begin{array}{l}\text { NZA- } \\
11510\end{array}$} & 805 & $5750 \pm 60$ & $1 \sigma 6405-6561$ & 6485 \\
\hline & & & $2 \sigma 6319-6640$ & \\
\hline \multirow{2}{*}{$\begin{array}{l}\text { NZA- } \\
11512\end{array}$} & 720 & $5670 \pm 74$ & $1 \sigma 6308-6464$ & 6400 \\
\hline & & & $2 \sigma 6280-6626$ & \\
\hline
\end{tabular}

